\title{
Profession Driven Improvement of the Quality of Pharmacy Practice-Implementation of Community Pharmacy Services Quality Guidelines in Estonia
}

\author{
Kristiina Sepp ${ }^{1, *(\mathbb{D})}$, Afonso Miguel Cavaco ${ }^{1,2} \mathbb{D}$, Ain Raal $^{1}\left(\mathbb{D}\right.$ and Daisy Volmer ${ }^{1}$ (D) \\ 1 Institute of Pharmacy, Faculty of Medicine, University of Tartu, 50411 Tartu, Estonia; \\ acavaco@ff.ulisboa.pt (A.M.C.); ain.raal@ut.ee (A.R.); daisy.volmer@ut.ee (D.V.) \\ 2 Department of Social Pharmacy, Faculty of Pharmacy, University of Lisbon, 1649-004 Lisboa, Portugal \\ * Correspondence: kristiina.sepp@ut.ee; Tel.: +372-5112195
}

check for updates

Citation: Sepp, K.; Cavaco, A.M.; Raal, A.; Volmer, D. Profession Driven Improvement of the Quality of Pharmacy Practice-Implementation of Community Pharmacy Services Quality Guidelines in Estonia.

Healthcare 2021, 9, 804.

https://doi.org/10.3390/

healthcare 9070804

Academic Editor: Jitendra Singh

Received: 27 May 2021

Accepted: 24 June 2021

Published: 26 June 2021

Publisher's Note: MDPI stays neutra with regard to jurisdictional claims in published maps and institutional affiliations.

Copyright: (c) 2021 by the authors. Licensee MDPI, Basel, Switzerland. This article is an open access article distributed under the terms and conditions of the Creative Commons Attribution (CC BY) license (https:// creativecommons.org/licenses/by/ $4.0 /)$.

\begin{abstract}
Constant improvement of the quality of community pharmacy services is important in the development of contemporary patient care. A national and voluntary Community Pharmacy Services Quality Guidelines (CPSQG) was developed to formulate the principles of contemporary pharmacy services, including quality criteria for service provision. The purpose of this study was to identify the implementation of the CPSQG as a profession-driven initiative towards improving and harmonizing community pharmacy services in Estonia. Three cross-sectional electronic surveys were conducted among community pharmacies in Estonia in 2014 ( $\mathrm{N}=478$ pharmacies), $2016(\mathrm{~N}=493)$, and $2019(\mathrm{~N}=494)$, and the CPSQG indicators were used for evaluation of the service quality. In this study, the aggregated data, collected in three study years were used to identify the implementation of guidelines into practice. For data analysis, the One-Way ANOVA test and Post-hoc multiple comparisons were used. The results demonstrated slow implementation of the CPSQG, but guidelines-based evaluation enabled a detailed overview of the community pharmacy activities and provided services. In order to develop community pharmacy services more efficiently, the use of implementation science principles, continuous introduction of the CPSQG to the pharmacists, and more active involvement of the state could be considered in the future.
\end{abstract}

Keywords: community pharmacy service; quality indicators; self-assessment; pharmacists; Estonia

\section{Introduction}

Community pharmacy services are easily accessible healthcare services designed to provide counselling about self-treatment, safe and effective use of medicines, health promotion, and reliable healthcare resources [1]. There is a wide diversity in service names and classification, such as traditional and extended pharmacy services. In the post-socialist countries, with a low or uneven implementation of pharmaceutical care services, dispensing and counselling of non-prescription and prescription medicines, compounding of medicines, and health promotion could be seen as core or traditional services. In the group of extended services, it is possible to incorporate management of chronic diseases, including medicines use review; new medicines service; early screening and testing; vaccination; smoking cessation; and point of care testing to measure blood pressure, cholesterol, and glucose amongst others [2,3]. Internationally, the provision of comprehensive pharmacy services is not always regulated, or the scope of community pharmacies activities is limited to the provision of traditional pharmacy services [4]. However, in health care systems focusing on primary health care, the role of community pharmacists in counselling and monitoring drug therapy of the patient is becoming increasingly important. Also, community pharmacists are taking a more significant role in health promotion and prevention, patient education, chronic disease management, and immunizations, improving access to primary health care services [5]. 
In 1999, the Good Pharmacy Practice (GPP) standard, developed by the International Pharmaceutical Federation (FIP) and the World Health Organization (WHO), laid the foundation for quality of care in community and hospital pharmacy settings [6,7]. Following this joint guideline, many countries have established a national framework of quality standards. Depending on the scope of the GPP standard, the guidelines could be developed as independent documents, integrated into pharmaceutical legislation, or used as recommendations supporting legislative acts. For example, in Lithuania and Slovenia, the pharmacy regulator has adopted GPP standards, while in Serbia, GPP guidelines must be approved by the ministry of health. In Uzbekistan, the GPP guidelines, describing traditional community pharmacy services are optional [4].

Constant improvement of the quality of community pharmacy services is expected in the development of contemporary patient care. At the beginning of 2021, 479 community pharmacies were operating in Estonia, with an average of 2700 inhabitants per pharmacy, similar to other Eastern European countries [8-10]. Community pharmacies in Estonia have historically focused on traditional services such as compounding and dispensing medicines and providing drug information to pharmacy customers [11]. Existing extended services comprise disease prevention, e.g., flu vaccination, smoking cessation, measuring blood pressure and cholesterol [12-14]. Medication use review was first piloted in 2019 [15].

For the provision of community pharmacy services, the basic principles of WHO/FIP guidelines have been recognized by Estonian professionals and academic organizations. Besides, a national guideline was developed to complement the existing regulations, and ensure and evaluate the quality of pharmacy services. Profession-driven Community Pharmacy Services Quality Guidelines (CPSQG) were first compiled in 2012 and updated in 2016 and 2021, in cooperation with practicing pharmacists and professional organizations, state and educational institutions. The CPSQG aims to formulate the principles of contemporary pharmacy services, including quality criteria for service provision. CPSQG indicators enable the self-assessment by pharmacists of service quality and different operational aspects of community pharmacies in Estonia [16]. The guidelines serve as recommendations supporting pharmacy legislation and are not legally binding for community pharmacies. Therefore, it is essential to understand how the existing quality indicators contributed to community pharmacy services and quality of care. Systematic adherence to the principles of GPP guidelines could be seen as one of the handy possibilities for harmonizing the quality of community pharmacy services throughout the country in benefiting primary care and patient outcomes [7]. Despite several post-socialist countries having reported adaption of GPP standards, there is little information available on the role of community pharmacies in the health care system, quality of, and public and professional perceptions on services provided [4].

This study aimed to identify the implementation of the Community Pharmacy Services Quality Guidelines as a profession-driven initiative towards improving and harmonizing the quality of community pharmacy services in Estonia.

\section{Materials and Methods}

\subsection{Study Context}

In Estonia, the Medicinal Products Act establishes strict legal regulations for handling medicines and the operation of community pharmacies, forming an essential structure for the provision of high-quality pharmacy services. However, the content of the services (e.g., counselling of medicines) is described shortly, and there was a need for more detailed guidelines for community pharmacies. In collaboration with professional and academic organizations, the CPSQG was developed [17].

The initial concepts were gathered from different GPP international guidelines, particularly the frameworks of the United Kingdom, the United States, and Australia [18-20]. In addition, the principles of the Model for Improvement from the Institute for Healthcare Improvement (IHI) [21] were used in identifying the main goals of the developed guidelines and brainstorming drivers for change within CPSQG working group members and 
other stakeholders, e.g., representatives of General Practitioners Association. The four-level cycle of Plan, Do, Study and Act for quality improvement of the community pharmacy service was considered a suitable framework for implementing the CPSQG.

The CPSQG was organized into 10 chapters describing the community pharmacy service or activity and comprising indicators to enabling self-assessment by pharmacists. The indicators were validated in 2013 among 201 community pharmacies in Estonia. In addition to self-assessment, the pharmacists were also able to provide feedback on the feasibility and relevance of the indicators [22]. The validation procedures suggested that the dichotomous scale (yes/no) of responses was not always sufficient to assess the actual quality of services provided. Thus, the response scale was changed to a four-point scale (always/mostly/occasionally/never) for $1 / 2$ of the indicators. Also, based on the respondents' comments, the selection of indicators was updated.

The CPSQG was disseminated to all community pharmacies in Estonia in 2014, 2016, and 2021. An electronic version of the guidelines was also available from professional organizations and at the State Agency of Medicines webpage. Several seminars introducing the guideline were held in 2012-19 to raise awareness about CPSQG and leverage the implementation of the guidelines [23].

\subsection{Study Design and Sample}

Three cross-sectional electronic surveys were conducted among community pharmacies in Estonia in 2014 ( $\mathrm{N}=478$ pharmacies), $2016(\mathrm{~N}=493)$, and $2019(\mathrm{~N}=494)$ to follow-up the reception and application of the CPSQG. It was asked to fill in only one survey per pharmacy.

\subsection{Study Instrument}

The CPSQG was used as a self-assessment tool for community pharmacists to evaluate service quality. In this study, the aggregated data collected in 2014, 2016, and 2019 were used to identify the implementation of guidelines into practice. The self-assessment tool included indicators with a two-point ( 1 yes/ 0 no) or a four-point $(0$ never $/ 1$ occasionally / 2 mostly / 3 always) response scale. Pharmacy characteristics, such as geographical location and pharmacy type (main or branch pharmacy), were also registered.

In the self-assessment, 132 quality indicators of 172 in 2014, 137 of 168 in 2016, and 139 of 168 in 2019 were used. The quality indicators considered as recommendations for pharmacies (e.g., to have a separate locker for each employee) were excluded from the self-assessment. To assess the implementation of changes in pharmacy practice during the study period, only those indicators with results available for at least two years $(n=127)$ were included (Table 1).

Table 1. Indicators used in the implementation survey of the Community Pharmacy Services Quality Guidelines $(n=127)$.

\begin{tabular}{|c|c|c|}
\hline Themes $(n=3)$ & Sub-Themes $(n=10)$ & Quality Items $(n=127)$ \\
\hline \multirow{9}{*}{$\begin{array}{l}\text { Traditional community pharmacy } \\
\text { services }\end{array}$} & \multirow{3}{*}{ Prescription-only medicines (POM) } & Prescription check (3) \\
\hline & & Selection of medicines (7) \\
\hline & & Patient counselling on the use of POMs (14) \\
\hline & \multirow{3}{*}{$\begin{array}{l}\text { Self-treatment and non-prescription } \\
\text { medicines and other pharmacy goods }\end{array}$} & Evaluation of symptoms (6) \\
\hline & & Selection of treatment method (6) \\
\hline & & $\begin{array}{l}\text { Patient counselling on the use of OTCs or } \\
\text { other pharmacy goods (9) }\end{array}$ \\
\hline & \multirow{3}{*}{ Compounding of medicines } & $\begin{array}{l}\text { Handling of prescriptions for } \\
\text { extemporaneous medicines (4) }\end{array}$ \\
\hline & & Preparation of medicines (3) \\
\hline & & Quality of extemporaneous medicines (3) \\
\hline
\end{tabular}


Table 1. Cont.

\begin{tabular}{|c|c|c|}
\hline Themes $(n=3)$ & Sub-Themes $(n=10)$ & Quality Items $(n=127)$ \\
\hline \multirow{2}{*}{ Extended services } & \multirow{2}{*}{ Health promotion } & $\begin{array}{l}\text { Qualification of pharmacists for provision } \\
\text { of extended services (5) }\end{array}$ \\
\hline & & Provided extended services (5) \\
\hline \multirow{15}{*}{ Pharmacy environment and operation } & \multirow{2}{*}{$\begin{array}{l}\text { Premises and technical equipment of the } \\
\text { pharmacy }\end{array}$} & $\begin{array}{l}\text { Conditions for private and } \\
\text { patient-centred counselling (7) }\end{array}$ \\
\hline & & Service provision supporting tools (3) \\
\hline & \multirow{3}{*}{$\begin{array}{l}\text { Handling of medicines and } \\
\text { pharmaceutical goods }\end{array}$} & Procurement and ensuring stock (3) \\
\hline & & Storage and dispensing (5) \\
\hline & & Quality problems/management (4) \\
\hline & \multirow{3}{*}{ Pharmacy management } & Management of customer relations (6) \\
\hline & & Personnel management (2) \\
\hline & & Manager's responsibilities (4) \\
\hline & \multirow{4}{*}{ Communication } & Internal communication (3) \\
\hline & & External Communication (7) \\
\hline & & Communication obligation (2) \\
\hline & & $\begin{array}{l}\text { Pharmacist as a lecturer and author of } \\
\text { articles (1) }\end{array}$ \\
\hline & \multirow{2}{*}{ Pharmacists' training } & Pharmacists' lifelong learning (6) \\
\hline & & Pharmacy as a traineeship institution (4) \\
\hline & Legal requirements & Compliance with legal requirements (4) \\
\hline
\end{tabular}

\subsection{Data Analysis}

An eFormular platform (http: / / www.eformular.com, accessed on 10 February 2021) was used for data collection and initial analysis. Subsequently, data were imported into a Statistical Package for Social Sciences $\left(\right.$ SPSS $\left.^{\circledR}\right)$, v. 27. The results of different survey years were compared using the One-Way ANOVA test and Post-hoc multiple comparisons, after checking the sample homogeneity of variances with the Levene test. Data were tested for normality using the Kolmogorov-Smirnov test, and an alpha value lower than 0.05 for all variables was received. The statistical significance level was set at $p<0.05$. In the Results section, only statistically significant results are presented. If only two study years were available, results are presented using the Anova F value and p-value. However, if data for three reference years were available, the $\mathrm{p}$ values of the Post-hoc comparisons are used. The complete analysis of the three study years (i.e., mean values for different study years and $p$-value) can be found in Appendix A.

\subsection{Ethical Considerations}

The researchers followed the principles of medical ethics highlighted by Beauchamp and Childress in the 1970s [24] and Helsinki's Declaration [25]. The study organization and aims, including the participants' right to withdraw from the study at any time, were explained. The respondents' anonymity and data confidentiality were guaranteed; only characteristics as regional location and pharmacy type (branch or central pharmacy) were asked. Data collection, storage, and data analysis comply with the Personal Data Protection Act [26]. 


\section{Results}

\subsection{Description of Respondents}

In 2014 and 2016, more than $40 \%$ of community pharmacies operating in Estonia participated in the self-evaluation exercise (Figure 1). In 2019, the number of respondents decreased to a quarter of all community pharmacies. Compared to the other regions, there were more participants from the capital area $(p \leq 0.01)$.

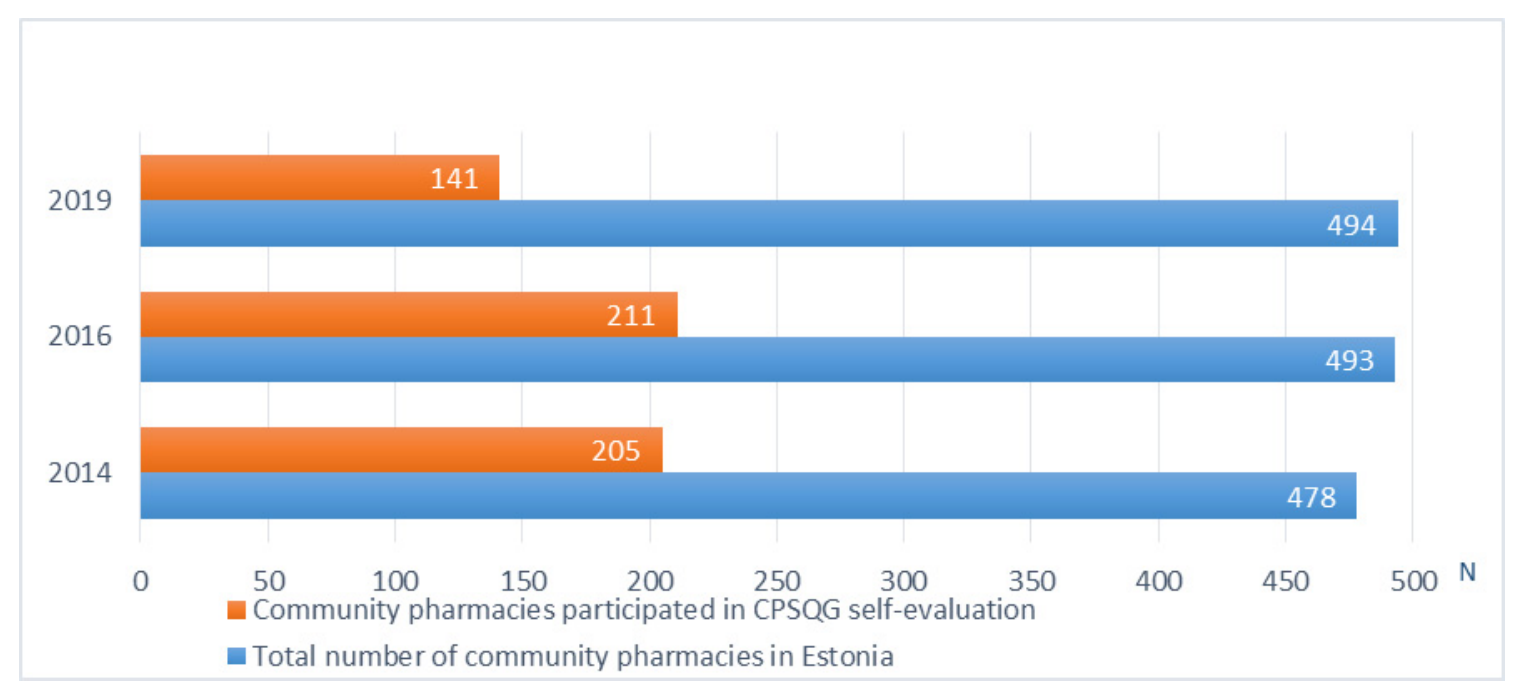

Figure 1. The number of community pharmacies participated in the self-assessment based on the Community Pharmacy Service Quality Guidelines in 2014-19 compared to all pharmacies operating in Estonia.

\subsection{Traditional Community Pharmacy Services}

Analysis of traditional community pharmacy services revealed no significant changes in counselling practices of both prescription-only medicines (POM) and over-the-counter (OTC) medicines during the study period. To some extent, the counselling quality was higher for OTC medicines and lower for POM medicines (Figure 2). However, this difference cannot be directly related to the implementation of the CPSQG; as there were no significant changes in counselling quality provided in the two groups of medicines mentioned above within the years the study was undertaken. The most concerning result was insufficient risk communication (adverse drug reactions, interactions, and contraindications) to patients with POMs (2014-19 Tukey $p=0.015)$ and OTCs (2014-19 Tukey $p=0.038$, also with a decreasing trend from 2014 to 2019. Besides, compared to the first study year, the consultation about different medical devices (e.g., inhalators) has decreased in the last two study years (2014-16 Tamhane $p<0.001 ; 2014-19$ Tamhane $p=0.003$ ).

The compounding of medicines had decreased through the years at community pharmacies in Estonia $(\mathrm{F}=3.341, p=0.036)$. In a pharmacy where the compounding of medicines was not obligatory (pharmacies operating in an area with less than 4000 inhabitants or branch pharmacies), no other pharmacies were sought where the patients could have their medicine prepared $(\mathrm{F}=165.948, p<0.001)$. On the other hand, when the medicine was prepared, the patient received it within two days at the latest, and during study years, this time has shortened (2014-16 Tamhane $p<0.001 ; 2014-19$ Tamhane $p=0.004)$.

\subsection{Extended Community Pharmacy Services}

CPSQG indicators enabled the assessment of the frequency of extended services provision but not their quality. Similarly to the traditional services, no significant changes have been found in providing extended services during the study period. Point-of-care testing was the most common extended service, of which only blood pressure measurement increased during the study period (2014-19 Tamhane $p=0.020$ ) (Figure 3). 
Information related to the pharmacy-based extended services (patient health indicators data) was always documented in about $1 / 5$ pharmacies in all study years. Participation at health and environmental campaigns outside of pharmacies decreased significantly (2014-16 Tamhane $p<0.001 ; 2014-19$ Tamhane $p<0.001$ ).

To be able to provide quality extended services additional training is required. In about a third of pharmacies, pharmacy staff providing extended services had completed the relevant training; however, participation in further training has decreased significantly in the last survey year $(\mathrm{F}=10.876, p<0.001)$.

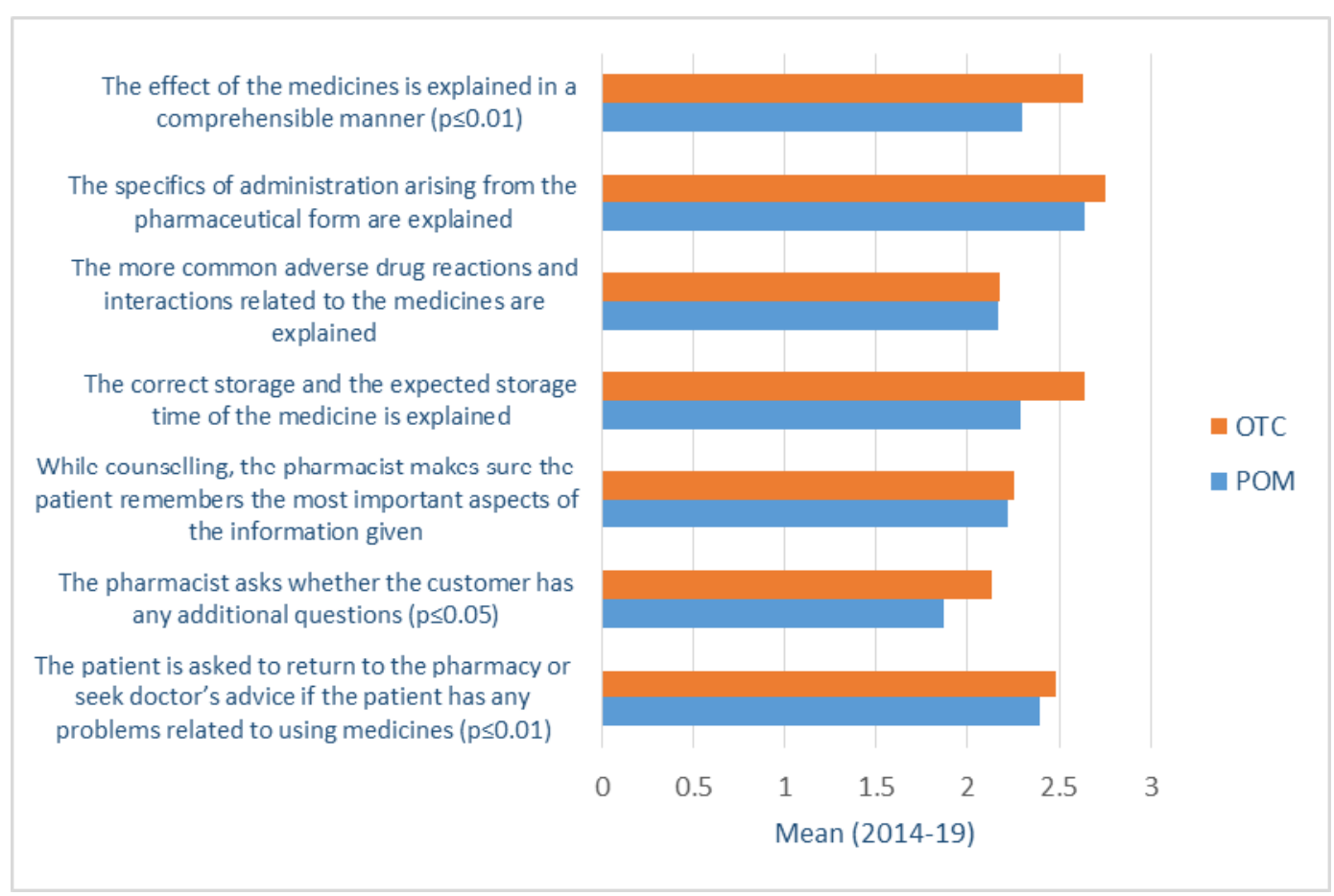

Figure 2. Patient counselling about OTCs and POMs based on the evaluation of the Community Pharmacy Service Quality Guideline (four-point scale) in 2014-19.

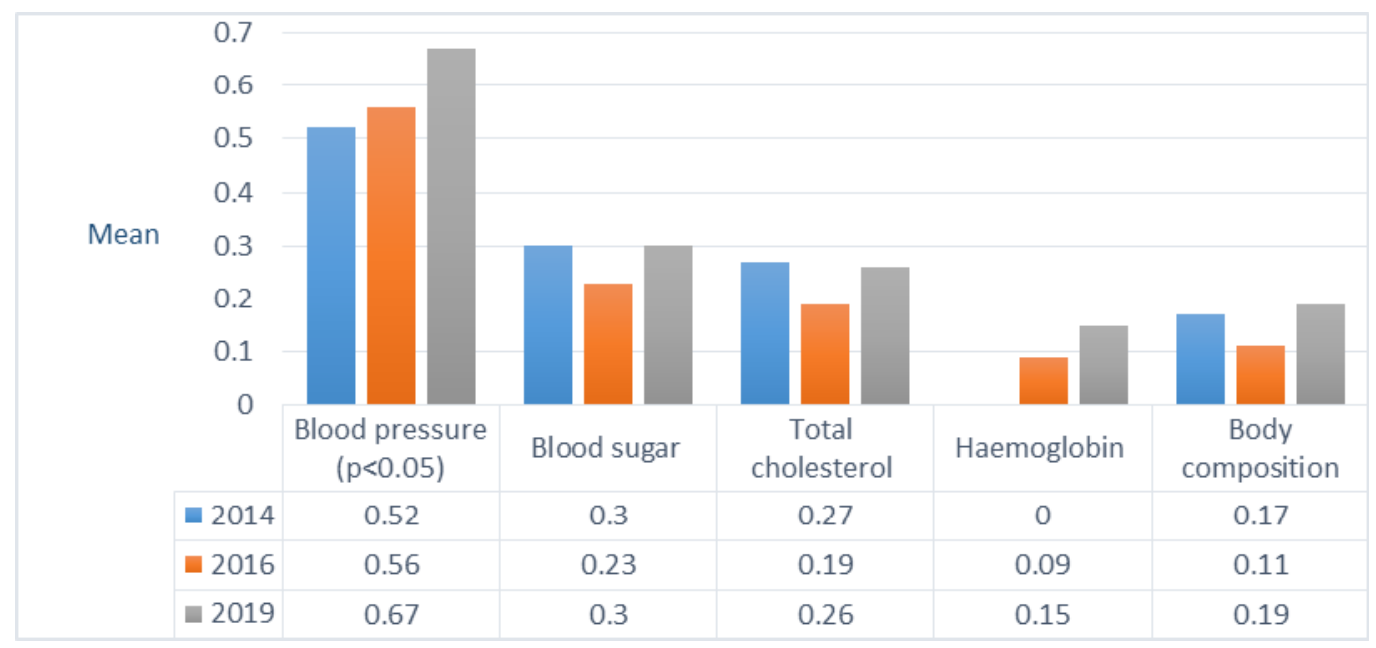

Figure 3. Provision of extended services based on evaluating the Community Pharmacy Service Quality Guideline (twopoint scale) in 2014-19. 


\subsection{Pharmacy Environment and Operation}

A few pharmacies (in 2019 16\%) in Estonia have a separate consultation room or private counselling possibilities in the sales area for POM and OTC medicines. This situation did not change during the study period. On the other hand, many pharmacies provided customers with a seating area and drinking water to administer the medicine (2014-16 Tamhane $p<0.001 ; 2014-19$ Tamhane $p<0.001$ ) (Figure 4).

Use of different service provision supporting tools, e.g., to assess the stock (2014-16 Tamhane $p=0.006 ; 2014-19$ Tamhane $p=0.017 ; 2016-19$ Tamhane $p<0.001$ ), to monitor expiry date of medicines $(\mathrm{F}=4.561, p=0.033)$, to prevent errors during dispensing medicines, to check potential interactions and adverse drug reactions has decreased within the study period. At the same time, pharmacists did not have direct external channels to receive quick information about medication shortages, which has increased during the study years (2014-16 Tukey $p=0.033$ ). Also, if the product was not available in the pharmacy stock, it was time-consuming to find it from the medicine wholesalers, and pharmacists' willingness to make inquiries for resolving the situation has significantly decreased (2014-16 Tamhane $p=0.033$; 2014-19 Tamhane $p=0.005$ ).

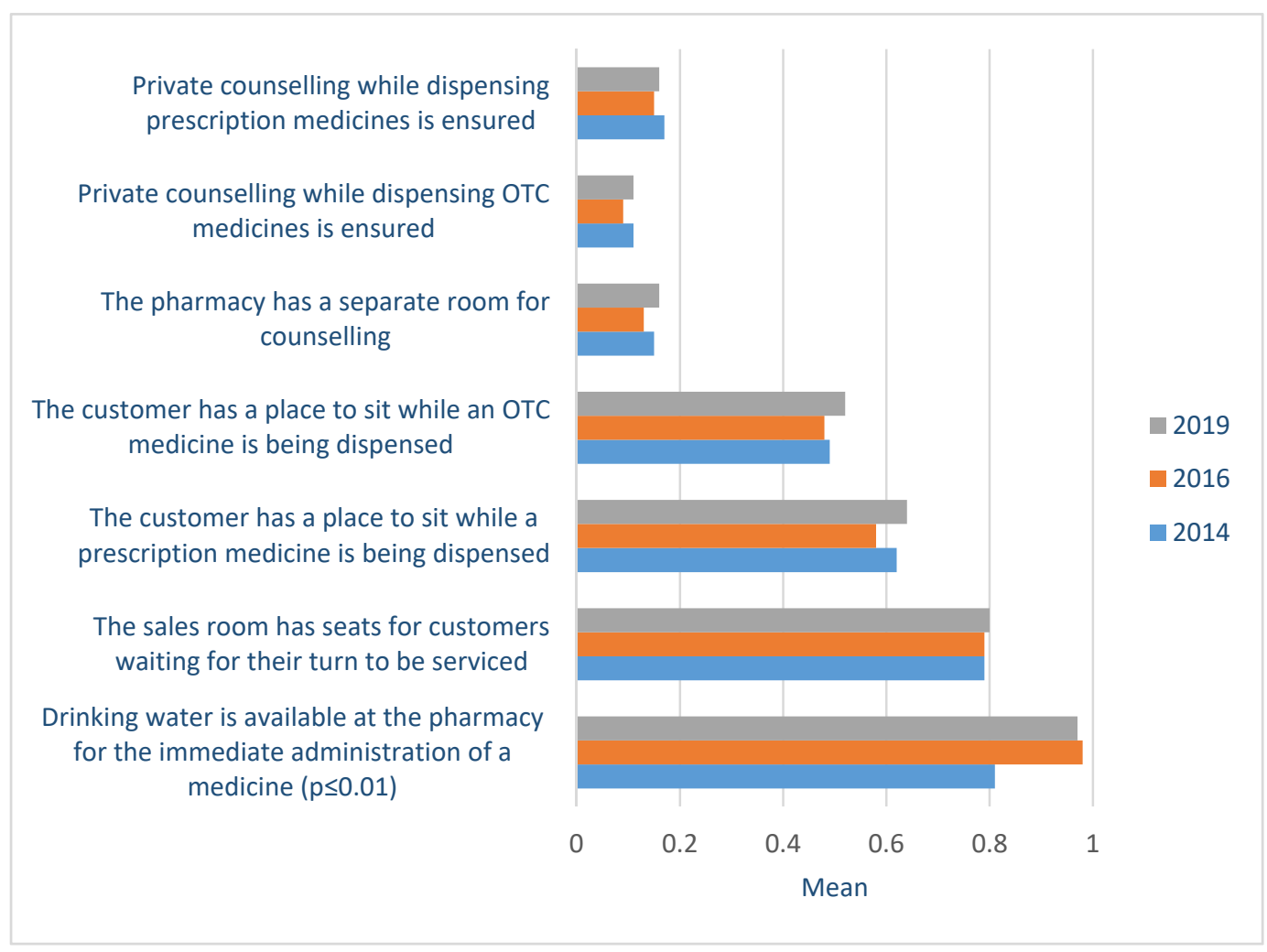

Figure 4. Private counselling availability, seating possibilities, and drinking water for pharmacy customers at community pharmacies based on the evaluation of the Community Pharmacy Service Quality Guidelines (two-point scale) in 2014-19.

To ensure a high-quality service, a competent and capable pharmacy manager and a sufficient number of professional staff are required amongst other resources. About half of the pharmacies that participated in the self-assessment in all study years reported consistently to have implemented all the activities needed for efficient management, including a supportive and motivating working environment. For instance, all employees followed unified customer service principles, regular feedback from customers and staff members about service provision was obtained, and an existing system for disseminating important information was in operation. However, about $2 / 3$ of the respondents reported a shortage of professional staff in their pharmacy and this problem increased during study years (2014-19 Tamhane $p=0.003$ ). Despite the shortage of professional staff and less flexible 
management of human resources, the participation in the continuous professional development of pharmacists throughout the years had become more systematic, and the interest of pharmacists in acquiring knowledge had grown (Figure 5).

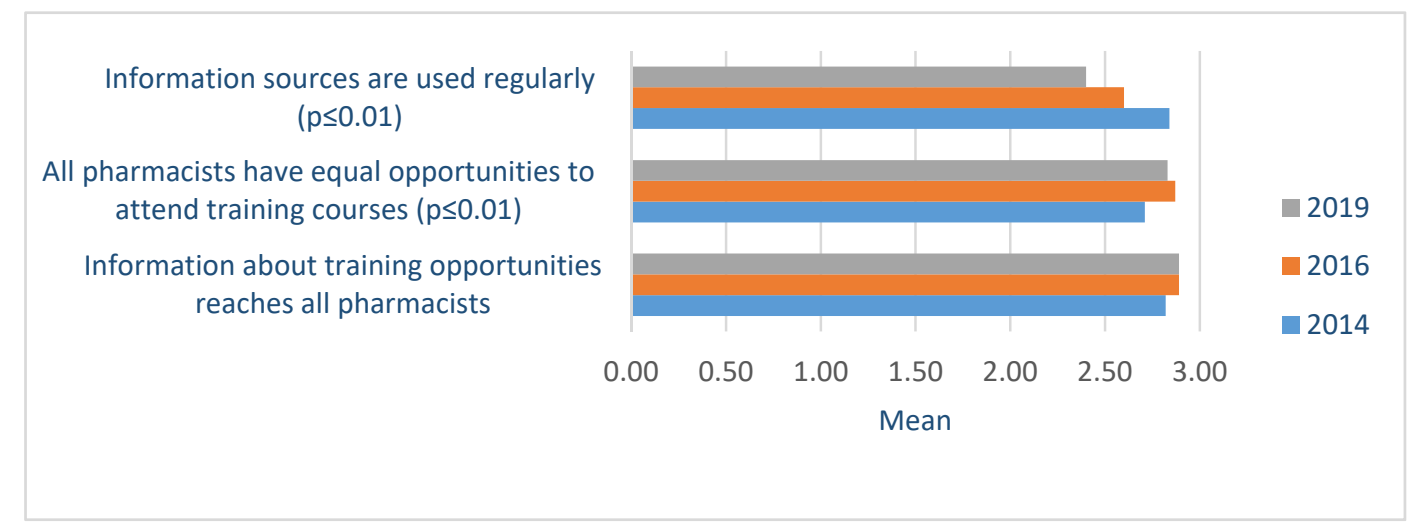

Figure 5. Following the principles of lifelong learning by community pharmacists based on the evaluation of the Community Pharmacy Services Quality Guidelines (four-point scale) in 2014-19.

\section{Discussion}

In post-socialist countries, the reforms in the pharmacy sector started with the privatization of community pharmacies. During the last thirty years, community pharmacy systems have undergone liberalization with ownership and establishment of community pharmacies not limited to the pharmacy profession and the opening of pharmacy chains [27-29]. Within this specific context, the leading professional task has been assuring the quality of traditional community pharmacy services, not primarily the development of new or extended services $[27,28]$. Nevertheless, there have been professional and practice developments in Lithuania and Bulgaria, attempting to introduce pharmaceutical care services into community pharmacy practice, driven mainly by profession and with little government involvement [30,31].

Internationally, GPP standards have defined the structure, process, and outcome measures for core or traditional services, such as dispensing and counselling POMs and OTCs, and compounding medicines [32-34]. Based on similar principles, the community pharmacy sector in Estonia has developed the Community Pharmacy Service Quality Guidelines (CPSQG) framework, a professional initiative to standardize and improve the quality of community pharmacy services. Measurable quality indicators enable pharmacists to assess the standard of services offered and to undertake respective changes, if necessary. The CPSQG allows active monitoring of the quality of services and supports the implementation efforts towards the necessary changes. The CPSQG self-assessment results from 2014 to 2019, carried out three times after introducing the guidelines in 2012, demonstrated a slow change in the quality of community pharmacy services. This finding suggests the CPSQG was applied to evaluate the activities and services of pharmacies instead of using the framework to improve the quality of the service. Implementation science might help to explain the developed situation where the only use of a quality framework is not sufficient for voluntary practice improvements. Compliance with new and not law enforced professional behaviors may be low due to the short implementation period of the standards.

\subsection{Operation of and Service Quality at Community Pharmacies}

This study highlighted anticipated issues but demonstrated new developments in service provision at community pharmacies and the professional activity of community pharmacists in Estonia. For example, compared to previous studies, drug communication and patient consultation have increased for OTC medicines [35]. On the other hand, POM counselling quality has not changed, and this might be explained by the limited 
access and/or use of patient health records. In Estonia, pharmacists can access an agreed health data set (all prescribed POMs and since 2018 with diagnosis codes) of a patient [36]; however, the use of this information in patient counselling seems to need more implementation into practice. According to the international experience, involving a pharmacist in counselling on prescription medicines has an important impact on patient health outcomes, saves cost in first-time medicines users, and covers pharmacovigilance aspects [37].

Poor communication of safety-related information (contraindications, adverse drug reactions, and interactions) to the patient had already been reported in previous studies in Estonia $[38,39]$ and was also confirmed in the CPSQG-based self-assessment. This is not a problem accessing reliable and up-to-date drug-related information since pharmacists in Estonia may use the official database to identify drug interactions and adverse drug reactions (Inxbase). Also, the Estonian Health Insurance Fund allows free database access and operation to pharmacists for evaluating the interactions between OTC medicines and food supplements [40]. However, most pharmacies do not seem to be able to use this tool, and if they do, it remains unclear how often this source is used, what sections, and for what reasons. To provide high-quality and patient-centered pharmacy service, pharmacists should have access to the same databases and the same extent as other healthcare professionals.

Different technology tools or systems (e.g., to assess the stock, monitor expiry date of medicines, prevent errors while dispensing medicines) for service provision decrease administrative burden and allow more patient-focused care in community pharmacies [5,41]. Although all community pharmacies in Estonia are computerized and $99 \%$ of prescriptions are e-prescriptions [42], the comparison between the study years showed a slight decrease in exploiting different daily operation tools. Of particular concern is the decreasing activity of pharmacists in dealing with medicines shortages and stock-outs. According to the Pharmaceutical Group of European Union (PGEU) medicines shortages survey, this problem may affect community pharmacy businesses by reducing patients' trust and financial loss due to time invested in mitigating shortages and reducing employee satisfaction [43]. The unavailability of medicines has a crucial impact on patient health outcomes, where pharmacies should show higher initiative at the patient-care level. For example, active communication with drug regulators and other stakeholders, including other pharmacies and prescribers, could be increased to share information about medicines shortages and find (temporary) solutions to ensure continuity of patient care.

\subsection{Competency of Community Pharmacists and Pharmacy Environment}

Cipolle et al. have highlighted that community pharmacists were most comfortable and confident while dispensing medicines [44]. Self-confidence and higher professionalism are related to professional knowledge and continuous self-development [45]. Following lifelong learning principles are essential throughout the professional career to ensure upto-date knowledge and skills. Results have shown that the organization of continuous professional development (CPD) has significantly improved during the study. This can be explained by the fact that since 2015 it is mandatory for all pharmacists in Estonia to collect $40 \mathrm{CPD}$ hours within two years. However, the impact and application of the training to the actual pharmacy practice has not been evaluated or monitored to date [17]. More CPD features should be implemented, including self-reflection and documentation as well as skills demonstration by simulated practice. This would require more effort from the learner and provide more precision in professional progress $[45,46]$. Additionally, a community pharmacy sector vision document till 2030 outlined the importance of a unified and integrated system of under- and postgraduate education of pharmacists in Estonia [47].

The provision of extended services has not changed during the study period, and mostly point-of-care testing was offered. However, since 2018 community pharmacies have contributed to flu vaccination and since 2019, to harm reduction services i.e., needle exchange [14,48]. In 2019-20 a medication use review (MUR) pilot service with a standardized structure and documentation form was introduced in five community pharmacies. Accord- 
ing to the pilot results, the service is important for chronic patients with polypharmacy as frequent drug-related problems, including low medicines adherence, were identified. Broader MUR provision requires more effective cooperation with general practitioners, pharmacists' access to patient health records, and finding sources for extra funding [15]. Comprehensive pharmacy services have gained little national appreciation, and some are even portrayed as controversial by policymakers and other healthcare professionals [49].

Both traditional and extended services require privacy for patient consultation. This study demonstrated that a private counselling area and/or a separate room were available in a small number of pharmacies. Due to the COVID-19 pandemic, the use of protective equipment and glass barriers on the counter might, even more, impede the quality of the pharmacist-patient interaction and communication. In contrast, the information provided by a pharmacist may be even more general [50]. The design of the healthcare environment affects various aspects of patient-centered care, including medication safety and counselling experience [51,52].

\subsection{Factors That May Have Influenced the Uptake of CPSQG}

Despite the intrinsic motivation of professionals to find ways to advance the quality of pharmacy practice, several other factors could have influenced the operation of community pharmacies to stall the aimed improvement in service quality.

Firstly, over the last ten years, the pharmaceutical policy in Estonia has developed hectically. While more attention has been paid to ensuring the availability of medicines [53], the development and evaluation of aspects of the rational use of medicines, including quality dispensing of medicines, has not been significantly addressed by health authorities [54]. Also, constant legislative changes in pharmacies establishment rules might have affected the quality and the development of the community pharmacy service. In this study, the participation in the 2019 survey was lower than in the previous two years, which could be explained by significant confusion related to the community pharmacy ownership reform in April 2020 [55,56].

Secondly, the development of a patient-centered service is complicated if the financing of the pharmacy services is product-based [17]. In Estonia, no legislation supports additional funding for the extended services (e.g., disease prevention or medication use review), although several countries have introduced alternative reimbursement models that link the level of funding to the quality of services provided by pharmacists $[57,58]$. Dispensing fees should be connected to the effort pharmacists make to improve the use of medicines so that people are more likely to take the medicines as prescribed. As an alternative, a prescription or service fee could be introduced similarly to, e.g., the Netherlands and Canada, to support counselling practice at the community pharmacy $[59,60]$.

Thirdly, with the introduction of longer opening hours and an open sales hall of pharmacies, there is a shortage of professional staff at community pharmacies in Estonia, affecting service quality. Considering the potential of pharmacy services for advising people in need of help, meeting the staff requirements is extremely important. Also, to ensure quality and efficient use of resources, it is necessary to know and use the competencies of different healthcare professionals like doctors, nurses, and pharmacists [61]. In order to cooperate more effectively with other healthcare professionals, it is first important to define the professional role of the pharmacist and the professional knowledge required to provide quality pharmacy service. Systematization of CPD courses or specialization, e.g., clinical pharmacist, could be seen as one solution to improve the pharmacy practice.

Fourth, pharmacy practice can also be affected by organizational and environmental issues [62]. Management and present managerial skills play an essential role in shaping the culture of an organization. Only half of the pharmacies that participated in this study had implemented all the activities described in CPSQG for effective, efficient, inclusive, and motivating management. Lack of solid leadership prevents the pharmacies from achieving the set goals and changing daily practice by putting the service provision focused on the patients [63]. 
Fifth, there is a need for a unified and robust vision regarding the role of community pharmacies in society. The tasks of pharmacists as healthcare professionals must be defined at a national level. The progress in pharmacy services has been achieved due to internal professional initiatives led by the pharmacy and less by the government and health authorities. Also, the lack of a single umbrella organization of community pharmacies in Estonia affects the sector's development [49].

\section{Conclusions}

The Community Pharmacy Service Quality Guidelines (CPSQG) was proposed as a critical professional initiative to improve the quality of community pharmacy practice in Estonia. However, the implementation of CPSQG at community pharmacies was slow and did not significantly change the quality of community pharmacy services indicating the need for exploitation of implementation science in the subsequent developments, preferably with governmental acknowledgement and support. Nevertheless, the CPSQG initiative enabled active monitoring of the community pharmacy operation and provided services based on a framework that aims to reach better patient health outcomes.

Author Contributions: Conceptualization, methodology, validation, writing-original draft preparation K.S. and D.V.; formal analysis, K.S.; writing-review and editing, K.S., A.M.C., A.R. and D.V. All authors have read and agreed to the published version of the manuscript.

Funding: This research received no external funding.

Institutional Review Board Statement: Not applicable.

Informed Consent Statement: Not applicable.

Acknowledgments: The authors thank CPSQG working group for collaboration and Kristina Lenbaum, Minna-Mari Salm and Airi Koppel for data collection and initial analysis.

Conflicts of Interest: The authors declare no conflict of interest.

\section{Appendix A}

List of quality indicators used in 2014, 2016 and 2019 for self-assessment of the quality of community pharmacy services in Estonia and assessment results.

\begin{tabular}{|c|c|c|c|c|c|c|c|}
\hline $\begin{array}{l}\text { Traditional } \\
\text { Pharmacy } \\
\text { Service }\end{array}$ & Quality Indicators & $\begin{array}{c}\text { Scale } \\
\text { Range } \\
(0-1 ; 0-3)\end{array}$ & $\begin{array}{l}2014 \text { Mean } \\
(0-1 ; 0-3) \\
\pm \text { Std }\end{array}$ & $\begin{array}{l}2016 \text { Mean } \\
(0-1 ; 0-3) \\
\quad \pm \text { Std }\end{array}$ & $\begin{array}{l}2019 \text { Mean } \\
(0-1 ; 0-3) \\
\quad \pm \text { Std }\end{array}$ & $\begin{array}{l}\text { Total Mean } \\
(0-1 ; 0-3) \\
\quad \pm \text { Std }\end{array}$ & $p \leq 0.05$ \\
\hline \multirow{3}{*}{$\begin{array}{l}\text { Checking } \\
\text { correction of } \\
\text { prescription } \\
\text { (3 indicators) }\end{array}$} & $\begin{array}{l}\text { Prescription is not } \\
\text { correctly/fully prepared, } \\
\text { the pharmacist } \\
\text { makes inquiries. }\end{array}$ & 4 & $\begin{array}{c}2.59 \\
\pm 0.73\end{array}$ & $\begin{array}{c}2.34 \\
\pm 0.88\end{array}$ & $\begin{array}{c}2.36 \\
\pm 0.84\end{array}$ & $\begin{array}{c}2.43 \\
\pm 0.83\end{array}$ & 0.004 \\
\hline & $\begin{array}{l}\text { Always identify the buyer } \\
\text { of the medicine based on } \\
\text { the identification } \\
\text { document. }\end{array}$ & 2 & $\begin{array}{c}1.0 \\
\pm 0.07\end{array}$ & $\begin{array}{c}0.99 \\
\pm 0.12\end{array}$ & $\begin{array}{c}0.98 \\
\pm 0.14\end{array}$ & $\begin{array}{c}0.99 \\
\pm 0.11\end{array}$ & 0.391 \\
\hline & $\begin{array}{l}\text { Find out whether this is the } \\
\text { first or repeat prescription } \\
\text { for the patient. }\end{array}$ & 4 & $\begin{array}{c}2.6 \\
\pm 0.52 \\
\end{array}$ & $\begin{array}{c}2.62 \\
\pm 0.52 \\
\end{array}$ & $\begin{array}{c}2.66 \\
\pm 0.49 \\
\end{array}$ & $\begin{array}{c}2.62 \\
\pm 0.51 \\
\end{array}$ & 0.57 \\
\hline \multirow[b]{2}{*}{$\begin{array}{l}\text { Selection of } \\
\text { medicines (7) }\end{array}$} & $\begin{array}{l}\text { First the cheapest medicine } \\
\text { is recommended to } \\
\text { the patient. }\end{array}$ & 4 & $\begin{array}{c}2.64 \\
\pm 0.54\end{array}$ & $\begin{array}{c}2.65 \\
\pm 0.48\end{array}$ & $\begin{array}{c}2.62 \\
\pm 0.53\end{array}$ & $\begin{array}{c}2.64 \\
\pm 0.51\end{array}$ & 0845 \\
\hline & $\begin{array}{l}\text { The compatibility of the } \\
\text { pharmaceutical form to the } \\
\text { treatment regimen } \\
\text { is checked. }\end{array}$ & 4 & - & $\begin{array}{c}2.75 \\
\pm 0.51\end{array}$ & $\begin{array}{c}2.78 \\
\pm 0.43\end{array}$ & $\begin{array}{c}2.76 \\
\pm 0.48\end{array}$ & 0.552 \\
\hline
\end{tabular}




\begin{tabular}{|c|c|c|c|c|c|c|c|}
\hline & $\begin{array}{l}\text { The asked medicine is out } \\
\text { of stock, the pharmacist } \\
\text { orders the medicine to the } \\
\text { pharmacy or sends the } \\
\text { patient to another suitable } \\
\text { pharmacy, having agreed } \\
\text { on that with the other } \\
\text { pharmacy beforehand. }\end{array}$ & 4 & - & $\begin{array}{c}2.83 \\
\pm 0.38\end{array}$ & $\begin{array}{c}2.74 \\
\pm 0.44\end{array}$ & $\begin{array}{c}2.80 \\
\pm 0.40\end{array}$ & 0.054 \\
\hline & $\begin{array}{l}\text { If the required medicine is } \\
\text { missing from the wholesale } \\
\text { network, the pharmacist } \\
\text { makes inquiries. }\end{array}$ & 4 & $\begin{array}{c}2.67 \\
\pm 0.56\end{array}$ & $\begin{array}{l}2.53 \\
\pm 0.62\end{array}$ & $\begin{array}{c}2.45 \\
\pm 0.68\end{array}$ & $\begin{array}{c}2.56 \\
\pm 0.62\end{array}$ & 0.003 \\
\hline & $\begin{array}{l}\text { The dose of the medicine } \\
\text { remains within the usual } \\
\text { limits (considering the } \\
\text { patient's age) is checked. }\end{array}$ & 4 & $\begin{array}{c}2.64 \\
\pm 0.58\end{array}$ & $\begin{array}{c}2.65 \\
\pm 0.56\end{array}$ & $\begin{array}{c}2.75 \\
\pm 0.48\end{array}$ & $\begin{array}{c}2.67 \\
\pm 0.55\end{array}$ & 0.146 \\
\hline & $\begin{array}{l}\text { The amount of the } \\
\text { prescription medicine } \\
\text { complies with the } \\
\text { treatment period } \\
\text { is assessed. }\end{array}$ & 4 & $\begin{array}{c}2.62 \\
\pm 0.55\end{array}$ & $\begin{array}{c}2.70 \\
\pm 0.48\end{array}$ & $\begin{array}{c}2.73 \\
\pm 0.46\end{array}$ & $\begin{array}{c}2.68 \\
\pm 0.50\end{array}$ & 0.117 \\
\hline & $\begin{array}{l}\text { The pharmacist checks } \\
\text { whether the medicine has } \\
\text { any contraindications in } \\
\text { the particular case. }\end{array}$ & 4 & $\begin{array}{c}2.19 \\
\pm 0.68\end{array}$ & $\begin{array}{c}2.20 \\
\pm 0.74\end{array}$ & $\begin{array}{l}2.44 \\
\pm 0.70\end{array}$ & $\begin{array}{l}2.25 \\
\pm 0.71\end{array}$ & 0.002 \\
\hline \multirow{7}{*}{$\begin{array}{l}\text { Patient } \\
\text { counselling } \\
\text { on the use of } \\
\text { POMs (14) }\end{array}$} & $\begin{array}{l}\text { The usage guidelines are } \\
\text { always written on the } \\
\text { package of the medicine } \\
\text { unless the patient asks } \\
\text { not to. }\end{array}$ & 2 & - & $\begin{array}{c}0.99 \\
\pm 0.12\end{array}$ & $\begin{array}{c}0.96 \\
\pm 0.20\end{array}$ & $\begin{array}{c}0.97 \\
\pm 0.16\end{array}$ & 0.099 \\
\hline & $\begin{array}{l}\text { The name of the patient is } \\
\text { written on the package of } \\
\text { the medicine. }\end{array}$ & 4 & $\begin{array}{c}1.0 \\
\pm 0.63\end{array}$ & $\begin{array}{c}0.85 \\
\pm 0.67\end{array}$ & $\begin{array}{c}2.61 \\
\pm 0.67\end{array}$ & $\begin{array}{c}1.35 \\
\pm 0.98\end{array}$ & $<0.001$ \\
\hline & $\begin{array}{l}\text { The patient is advised to } \\
\text { read the information leaflet } \\
\text { contained in the package. }\end{array}$ & 4 & - & $\begin{array}{l}1.83 \\
\pm 0.76\end{array}$ & $\begin{array}{c}1.87 \\
\pm 0.76\end{array}$ & $\begin{array}{c}1.85 \\
\pm 0.75\end{array}$ & 0.705 \\
\hline & $\begin{array}{l}\text { The effect of the medicine } \\
\text { is explained in a } \\
\text { comprehensible manner. }\end{array}$ & 4 & - & $\begin{array}{c}2.26 \\
\pm 0.68\end{array}$ & $\begin{array}{c}2.38 \\
\pm 0.59\end{array}$ & $\begin{array}{c}2.30 \\
\pm 0.65\end{array}$ & 0.090 \\
\hline & $\begin{array}{l}\text { The specifics of } \\
\text { administration arising from } \\
\text { the pharmaceutical form } \\
\text { are explained. }\end{array}$ & 4 & $\begin{array}{c}2.62 \\
\pm 0.55\end{array}$ & $\begin{array}{c}2.58 \\
\pm 0.62\end{array}$ & $\begin{array}{c}2.76 \\
\pm 0.49\end{array}$ & $\begin{array}{c}2.64 \\
\pm 0.57\end{array}$ & 0.014 \\
\hline & $\begin{array}{l}\text { The more common adverse } \\
\text { drug reactions and } \\
\text { interactions related to the } \\
\text { medicine are explained. }\end{array}$ & 4 & $\begin{array}{c}2.10 \\
\pm 0.66\end{array}$ & $\begin{array}{c}2.18 \\
\pm 0.70\end{array}$ & $\begin{array}{c}2.28 \\
\pm 0.61\end{array}$ & $\begin{array}{c}2.17 \\
\pm 0.67\end{array}$ & 0.049 \\
\hline & $\begin{array}{l}\text { The patient is counselled } \\
\text { on the use of tools needed } \\
\text { for the administration of } \\
\text { the medicine (e.g., insulin } \\
\text { needles, syringes, } \\
\text { nebulisers, etc.). }\end{array}$ & 4 & $\begin{array}{c}2.55 \\
\pm 0.64\end{array}$ & $\begin{array}{c}2.31 \\
\pm 0.73\end{array}$ & $\begin{array}{c}2.30 \\
\pm 0.71\end{array}$ & $\begin{array}{c}2.40 \\
\pm 0.70\end{array}$ & $<0.001$ \\
\hline
\end{tabular}




\begin{tabular}{|c|c|c|c|c|c|c|c|}
\hline & $\begin{array}{l}\text { The rate of medicines } \\
\text { action. }\end{array}$ & 2 & $\begin{array}{c}0.76 \\
+0.43\end{array}$ & $\begin{array}{c}0.61 \\
\pm 0.49\end{array}$ & $\begin{array}{c}0.96 \\
\pm 0.19\end{array}$ & $\begin{array}{c}0.76 \\
\pm 0.43\end{array}$ & $<0.001$ \\
\hline & $\begin{array}{l}\text { The correct storage and the } \\
\text { expected storage time of } \\
\text { the medicine is explained. }\end{array}$ & 4 & $\begin{array}{c}2.70 \\
\pm 0.52\end{array}$ & $\begin{array}{c}2.70 \\
\pm 0.52\end{array}$ & $\begin{array}{l}1.11 \\
\pm 0.88\end{array}$ & $\begin{array}{c}2.29 \\
\pm 0.93\end{array}$ & $<0.001$ \\
\hline & $\begin{array}{l}\text { The aspects of patient } \\
\text { about any lifestyle, general } \\
\text { condition and other factors } \\
\text { that may affect treatment } \\
\text { outcome is asked. }\end{array}$ & 4 & $\begin{array}{c}2.04 \\
\pm 0.73\end{array}$ & $\begin{array}{c}1.76 \\
\pm 0.72\end{array}$ & $\begin{array}{l}1.85 \\
\pm 0.75\end{array}$ & $\begin{array}{l}1.89 \\
\pm 0.74\end{array}$ & $<0.001$ \\
\hline & $\begin{array}{l}\text { Evidence-based additional } \\
\text { information about the } \\
\text { illness and/or the medicine } \\
\text { is given. }\end{array}$ & 4 & - & $\begin{array}{l}1.39 \\
\pm 0.65\end{array}$ & $\begin{array}{c}1.33 \\
\pm 0.69\end{array}$ & $\begin{array}{l}1.37 \\
\pm 0.67\end{array}$ & 0.446 \\
\hline & $\begin{array}{l}\text { While counselling, the } \\
\text { pharmacist makes sure the } \\
\text { patient remembers the } \\
\text { most important aspects of } \\
\text { the information given. }\end{array}$ & 4 & - & $\begin{array}{c}2.24 \\
\pm 0.70\end{array}$ & $\begin{array}{c}2.18 \\
\pm 0.73\end{array}$ & $\begin{array}{c}2.22 \\
\pm 0.71\end{array}$ & 0.500 \\
\hline & $\begin{array}{l}\text { If patient has any } \\
\text { additional questions about } \\
\text { the illness(es) or } \\
\text { medicine(s) is asked. }\end{array}$ & 4 & - & $\begin{array}{l}1.87 \\
\pm 0.78\end{array}$ & $\begin{array}{l}1.87 \\
\pm 0.82\end{array}$ & $\begin{array}{l}1.87 \\
\pm 0.80\end{array}$ & 0.981 \\
\hline & $\begin{array}{l}\text { The patient is asked to } \\
\text { return to the pharmacy or } \\
\text { seek doctor's advice if the } \\
\text { patient has any problems } \\
\text { related to using medicines. }\end{array}$ & 4 & $\begin{array}{c}2.38 \\
\pm 0.73\end{array}$ & $\begin{array}{c}2.39 \\
\pm 0.69\end{array}$ & $\begin{array}{l}2.39 \\
\pm 0.59\end{array}$ & $\begin{array}{c}2.39 \\
\pm 0.68\end{array}$ & 0.989 \\
\hline \multirow{6}{*}{$\begin{array}{l}\text { Evaluation of } \\
\text { health } \\
\text { problem } \\
\text { symptoms (6) }\end{array}$} & $\begin{array}{l}\text { Person who has the health } \\
\text { problem or needs the OTC } \\
\text { medicine and/or product } \\
\text { is identified. }\end{array}$ & 4 & $\begin{array}{l}2.92 \\
\pm 0.27\end{array}$ & $\begin{array}{c}2.97 \\
\pm 0.18\end{array}$ & $\begin{array}{c}2.93 \\
\pm 0.26\end{array}$ & $\begin{array}{c}2.94 \\
\pm 0.24\end{array}$ & 0.122 \\
\hline & Nature of discomfort. & 4 & $\begin{array}{c}2.89 \\
\pm 0.33\end{array}$ & $\begin{array}{c}2.93 \\
\pm 026\end{array}$ & $\begin{array}{c}2.91 \\
\pm 0.29\end{array}$ & $\begin{array}{c}2.91 \\
\pm 0.29\end{array}$ & 0.365 \\
\hline & Duration of discomfort. & 4 & $\begin{array}{l}2.70 \\
\pm 0.50\end{array}$ & $\begin{array}{c}2.83 \\
\pm 0.39\end{array}$ & $\begin{array}{l}2.72 \\
\pm 0.45\end{array}$ & $\begin{array}{l}2.75 \\
\pm 0.45\end{array}$ & 0.006 \\
\hline & Concomitant symptoms. & 4 & $\begin{array}{l}2.50 \\
\pm 0.56\end{array}$ & $\begin{array}{c}2.73 \\
\pm 0.44\end{array}$ & $\begin{array}{l}1.39 \\
\pm 0.72\end{array}$ & $\begin{array}{c}2.31 \\
\pm 0.78\end{array}$ & $<0.001$ \\
\hline & $\begin{array}{l}\text { Concomitant illnesses and } \\
\text { the use of (prescription) } \\
\text { medicines. }\end{array}$ & 4 & $\begin{array}{c}2.25 \\
\pm 0.67\end{array}$ & $\begin{array}{c}2.34 \\
\pm 0.63\end{array}$ & $\begin{array}{c}2.19 \\
\pm 0.74\end{array}$ & $\begin{array}{c}2.27 \\
\pm 0.68\end{array}$ & 0.113 \\
\hline & $\begin{array}{l}\text { If the patient's symptoms } \\
\text { are severe or their reason is } \\
\text { unclear, the pharmacist } \\
\text { advises the patient to see } \\
\text { a doctor. }\end{array}$ & 4 & $\begin{array}{c}2.87 \\
\pm 0.37\end{array}$ & $\begin{array}{c}2.78 \\
\pm 0.46\end{array}$ & $\begin{array}{c}1.91 \\
\pm 0.81\end{array}$ & $\begin{array}{c}2.59 \\
\pm 0.67\end{array}$ & $<0.001$ \\
\hline
\end{tabular}




\begin{tabular}{|c|c|c|c|c|c|c|c|}
\hline \multirow{6}{*}{$\begin{array}{l}\text { Selection of } \\
\text { treatment } \\
\text { method }(6)\end{array}$} & $\begin{array}{l}\text { On what purpose the } \\
\text { selected OTC medicines or } \\
\text { other pharmacy product } \\
\text { are going to be used } \\
\text { is assessed. }\end{array}$ & 4 & $\begin{array}{c}2.45 \\
\pm 0.57\end{array}$ & $\begin{array}{c}2.55 \\
\pm 0.59\end{array}$ & $\begin{array}{c}2.34 \\
\pm 0.71\end{array}$ & $\begin{array}{c}2.46 \\
\pm 0.62\end{array}$ & 0.008 \\
\hline & $\begin{array}{l}\text { What medicines, products } \\
\text { or treatments the patient } \\
\text { has used before and what } \\
\text { has been the result of } \\
\text { their use? }\end{array}$ & 4 & $\begin{array}{c}2.43 \\
\pm 0.60\end{array}$ & $\begin{array}{c}2.63 \\
\pm 0.55\end{array}$ & $\begin{array}{c}2.53 \\
\pm 0.56\end{array}$ & $\begin{array}{c}2.53 \\
\pm 0.57\end{array}$ & 0.003 \\
\hline & $\begin{array}{l}\text { Factors of customer that } \\
\text { may influence the choice } \\
\text { and treatment outcome of } \\
\text { the OTC medicine or other } \\
\text { pharmacy product } \\
\text { is identified. }\end{array}$ & 4 & $\begin{array}{c}2.37 \\
\pm 0.64\end{array}$ & $\begin{array}{c}2.60 \\
\pm 0.55\end{array}$ & $\begin{array}{c}2.91 \\
\pm 0.28\end{array}$ & $\begin{array}{c}2.59 \\
\pm 0.57\end{array}$ & $<0.001$ \\
\hline & $\begin{array}{l}\text { The cheapest/in different } \\
\text { price medicinal product } \\
\text { within the active substance } \\
\text { is informed. }\end{array}$ & 4 & $\begin{array}{c}2.57 \\
\pm 0.60\end{array}$ & $\begin{array}{c}2.69 \\
\pm 0.49\end{array}$ & $\begin{array}{c}2.88 \\
\pm 0.35\end{array}$ & $\begin{array}{c}2.69 \\
\pm 0.52\end{array}$ & $<0.001$ \\
\hline & $\begin{array}{l}\text { The pharmacist points out } \\
\text { important aspects of the } \\
\text { medicine and/or product } \\
\text { (e.g., taste, form and other } \\
\text { specifics of use, overdose } \\
\text { toxicity, contraindications). }\end{array}$ & 4 & $\begin{array}{c}2.49 \\
\pm 0.57\end{array}$ & $\begin{array}{c}2.46 \\
\pm 0.58\end{array}$ & $\begin{array}{c}2.72 \\
\pm 0.45\end{array}$ & $\begin{array}{c}2.54 \\
\pm 0.56\end{array}$ & $<0.001$ \\
\hline & $\begin{array}{l}\text { Where appropriate, the } \\
\text { possibility of non-medical } \\
\text { treatment will be suggested }\end{array}$ & 4 & $\begin{array}{c}2.06 \\
\pm 0.74\end{array}$ & $\begin{array}{c}2.11 \\
\pm 0.70\end{array}$ & $\begin{array}{c}2.58 \\
\pm 0.56\end{array}$ & $\begin{array}{c}2.21 \\
\pm 0.72\end{array}$ & $<0.001$ \\
\hline \multirow{5}{*}{$\begin{array}{l}\text { Patient } \\
\text { counselling } \\
\text { on the use of } \\
\text { OTCs or } \\
\text { other } \\
\text { pharmacy } \\
\text { goods (9) }\end{array}$} & $\begin{array}{l}\text { The effect of the } \\
\text { medicine/treatment } \\
\text { method is explained to the } \\
\text { customer in a } \\
\text { comprehensible manner. }\end{array}$ & 4 & $\begin{array}{c}2.65 \\
\pm 0.51\end{array}$ & $\begin{array}{c}2.61 \\
\pm 0545\end{array}$ & $\begin{array}{c}2.62 \\
\pm 0.52\end{array}$ & $\begin{array}{c}2.63 \\
\pm 0.52\end{array}$ & 0.654 \\
\hline & $\begin{array}{l}\text { The administration and } \\
\text { dosage of the medicine and } \\
\text { other relevant treatment } \\
\text { techniques are explained. }\end{array}$ & 4 & $\begin{array}{c}2.80 \\
\pm 0.42\end{array}$ & $\begin{array}{c}2.78 \\
\pm 0.41\end{array}$ & $\begin{array}{c}2.65 \\
\pm 0.52\end{array}$ & $\begin{array}{c}2.75 \\
\pm 0.45\end{array}$ & 0.007 \\
\hline & $\begin{array}{l}\text { The duration of the } \\
\text { treatment/use of the } \\
\text { treatment method is } \\
\text { explained. }\end{array}$ & 4 & $\begin{array}{c}2.62 \\
\pm 0.53\end{array}$ & $\begin{array}{c}2.66 \\
\pm 0.51\end{array}$ & $\begin{array}{c}2.67 \\
\pm 0.51\end{array}$ & $\begin{array}{c}2.65 \\
\pm 0.52\end{array}$ & 0.655 \\
\hline & $\begin{array}{l}\text { The correct storage of the } \\
\text { medicine and the expected } \\
\text { in-use storage time are } \\
\text { explained. }\end{array}$ & 4 & $\begin{array}{c}2.66 \\
\pm 0.57\end{array}$ & $\begin{array}{c}2.63 \\
\pm 0.58\end{array}$ & $\begin{array}{c}2.62 \\
\pm 056\end{array}$ & $\begin{array}{c}2.64 \\
\pm 0.57\end{array}$ & 0.773 \\
\hline & $\begin{array}{l}\text { The onset of action of the } \\
\text { medicine/treatment } \\
\text { method is explained. }\end{array}$ & 4 & $\begin{array}{c}2.20 \\
\pm 0.69\end{array}$ & $\begin{array}{c}2.03 \\
\pm 0.66\end{array}$ & $\begin{array}{c}2.50 \\
\pm 0.62\end{array}$ & $\begin{array}{c}2.21 \\
\pm 0.68\end{array}$ & $<0.001$ \\
\hline
\end{tabular}




\begin{tabular}{|c|c|c|c|c|c|c|c|}
\hline & $\begin{array}{l}\text { The more common adverse } \\
\text { drug reactions and } \\
\text { interactions related to the } \\
\text { medicine/treatment } \\
\text { method are explained. }\end{array}$ & 4 & $\begin{array}{c}2.24 \\
\pm 0.67\end{array}$ & $\begin{array}{c}2.22 \\
\pm 0.72\end{array}$ & $\begin{array}{c}2.02 \\
\pm 0.76\end{array}$ & $\begin{array}{c}2.18 \\
\pm 0.72\end{array}$ & 0.012 \\
\hline & $\begin{array}{l}\text { The pharmacist asks } \\
\text { whether the customer has } \\
\text { any additional questions. }\end{array}$ & 4 & - & $\begin{array}{c}2.11 \\
\pm 0.76\end{array}$ & $\begin{array}{c}2.16 \\
\pm 0.74\end{array}$ & $\begin{array}{c}2.13 \\
\pm 0.75\end{array}$ & 0.605 \\
\hline & $\begin{array}{l}\text { While counselling, the } \\
\text { pharmacist makes sure the } \\
\text { customer remembers the } \\
\text { most important aspects of } \\
\text { the information given. }\end{array}$ & 4 & - & $\begin{array}{c}2.24 \\
\pm 0.68\end{array}$ & $\begin{array}{c}2.26 \\
\pm 0.69\end{array}$ & $\begin{array}{c}2.25 \\
\pm 0.69\end{array}$ & 0.734 \\
\hline & $\begin{array}{l}\text { The patient is asked to } \\
\text { return to the pharmacy or } \\
\text { seek doctor's advice if the } \\
\text { patient has any problems } \\
\text { with using medicines. }\end{array}$ & 4 & $\begin{array}{c}2.49 \\
\pm 0.70\end{array}$ & $\begin{array}{c}2.45 \\
\pm 0.67\end{array}$ & $\begin{array}{c}2.50 \\
\pm 0.65\end{array}$ & $\begin{array}{c}2.48 \\
\pm 0.68\end{array}$ & 0.822 \\
\hline \multirow{4}{*}{$\begin{array}{l}\text { Handling of } \\
\text { prescriptions } \\
\text { for extempo- } \\
\text { raneous } \\
\text { medicines (4) }\end{array}$} & $\begin{array}{l}\text { The pharmacy has } \\
\text { prepared extemporaneous } \\
\text { medicines within the } \\
\text { past year. }\end{array}$ & 2 & $\begin{array}{c}0.44 \\
\pm 0.50\end{array}$ & $\begin{array}{c}0.34 \\
\pm 0.47\end{array}$ & $\begin{array}{c}0.31 \\
\pm 0.46\end{array}$ & $\begin{array}{c}0.37 \\
\pm 0.48\end{array}$ & 0.036 \\
\hline & $\begin{array}{l}\text { A pharmacy that is not } \\
\text { obliged to prepare } \\
\text { medicines arranges the } \\
\text { preparation of the medicine } \\
\text { at another pharmacy. }\end{array}$ & 2 & - & $\begin{array}{c}0.85 \\
\pm 0.36\end{array}$ & $\begin{array}{c}0.15 \\
\pm 0.36\end{array}$ & $\begin{array}{c}0.60 \\
\pm 0.49\end{array}$ & $<0.001$ \\
\hline & $\begin{array}{l}\text { The medicine is prepared } \\
\text { within } 48 \mathrm{~h} \text { from } \\
\text { submitting the } \\
\text { prescription. }\end{array}$ & 2 & $\begin{array}{c}0.40 \\
\pm 0.49\end{array}$ & $\begin{array}{c}0.71 \\
\pm 0.46\end{array}$ & $\begin{array}{c}0.60 \\
\pm 0.49\end{array}$ & $\begin{array}{c}0.54 \\
\pm 0.50\end{array}$ & $<0.001$ \\
\hline & $\begin{array}{l}\text { The pharmacy keeps } \\
\text { account of prescriptions on } \\
\text { the basis of which it was } \\
\text { not possible to prepare } \\
\text { medicines and documents } \\
\text { the reason. }\end{array}$ & 2 & - & $\begin{array}{c}0.24 \\
\pm 0.43\end{array}$ & $\begin{array}{c}0.16 \\
\pm 0.37\end{array}$ & $\begin{array}{c}0.21 \\
\pm 0.41\end{array}$ & 0.100 \\
\hline \multirow{3}{*}{$\begin{array}{l}\text { Preparation } \\
\text { of medicines } \\
\text { (3) }\end{array}$} & $\begin{array}{l}\text { The work is organised so } \\
\text { that the pharmacist does } \\
\text { not engage in other tasks } \\
\text { while preparing medicines. }\end{array}$ & 2 & - & $\begin{array}{c}0.83 \\
\pm 0.38\end{array}$ & $\begin{array}{c}0.69 \\
\pm 0.47\end{array}$ & $\begin{array}{c}0.76 \\
\pm 0.43\end{array}$ & 0.029 \\
\hline & $\begin{array}{l}\text { The pharmacy has } \\
\text { preparation instructions for } \\
\text { all medicines prepared. }\end{array}$ & 2 & $\begin{array}{c}0.37 \\
\pm 0.48\end{array}$ & $\begin{array}{c}0.70 \\
\pm 0.46\end{array}$ & $\begin{array}{c}0.51 \\
\pm 0.50\end{array}$ & $\begin{array}{c}0.49 \\
\pm 0.50\end{array}$ & $<0.001$ \\
\hline & $\begin{array}{l}\text { Each pharmacist who } \\
\text { prepares and inspects } \\
\text { medicines is well-informed } \\
\text { of the content of the } \\
\text { instructions on preparing } \\
\text { medicines. }\end{array}$ & 2 & - & $\begin{array}{c}0.84 \\
\pm 0.37\end{array}$ & $\begin{array}{c}0.73 \\
\pm 0.45\end{array}$ & $\begin{array}{c}0.79 \\
\pm 0.41\end{array}$ & 0.061 \\
\hline
\end{tabular}




\begin{tabular}{|c|c|c|c|c|c|c|c|}
\hline \multirow{3}{*}{$\begin{array}{l}\text { Quality of } \\
\text { extemporane- } \\
\text { ous } \\
\text { medicines (3) }\end{array}$} & $\begin{array}{l}\text { Organoleptic analysis is } \\
\text { performed on all } \\
\text { substances used for } \\
\text { preparing medicines before } \\
\text { their first use. }\end{array}$ & 2 & - & $\begin{array}{c}0.93 \\
\pm 0.26\end{array}$ & $\begin{array}{c}0.85 \\
\pm 0.36\end{array}$ & $\begin{array}{c}0.89 \\
\pm 0.31\end{array}$ & 0.096 \\
\hline & $\begin{array}{l}\text { According to the } \\
\text { inspections of the State } \\
\text { Agency of Medicines, the } \\
\text { medicines prepared at the } \\
\text { pharmacy have met the } \\
\text { quality standards during } \\
\text { the past three years. }\end{array}$ & 2 & $\begin{array}{c}0.35 \\
\pm 0.48\end{array}$ & $\begin{array}{c}0.84 \\
\pm 0.37\end{array}$ & $\begin{array}{c}0.78 \\
\pm 0.42\end{array}$ & $\begin{array}{c}0.55 \\
\pm 0.50\end{array}$ & $<0.001$ \\
\hline & $\begin{array}{l}\text { If a medicine is found not } \\
\text { to meet the requirements, } \\
\text { the reason of the } \\
\text { nonconformity is always } \\
\text { identified }\end{array}$ & 2 & $\begin{array}{c}0.36 \\
\pm 0.48\end{array}$ & $\begin{array}{c}0.89 \\
\pm 0.31\end{array}$ & $\begin{array}{c}0.71 \\
\pm 0.46\end{array}$ & $\begin{array}{c}0.53 \\
\pm 0.50\end{array}$ & $<0.001$ \\
\hline \multicolumn{8}{|l|}{$\begin{array}{l}\text { Extended } \\
\text { pharmacy } \\
\text { service }\end{array}$} \\
\hline \multirow{5}{*}{$\begin{array}{l}\text { Qualification } \\
\text { of employees } \\
\text { and } \\
\text { provision of } \\
\text { extended } \\
\text { services (5) }\end{array}$} & $\begin{array}{l}\text { All staff who provide the } \\
\text { extended service of health } \\
\text { promotion and illness } \\
\text { prevention have completed } \\
\text { the required training and } \\
\text { have a corresponding } \\
\text { certificate. }\end{array}$ & 2 & - & $\begin{array}{c}0.44 \\
\pm 0.50\end{array}$ & $\begin{array}{c}0.27 \\
\pm 0.44\end{array}$ & $\begin{array}{c}0.37 \\
\pm 0.48\end{array}$ & 0.001 \\
\hline & $\begin{array}{l}\text { All staff who measure } \\
\text { health indicators have } \\
\text { completed training for this } \\
\text { purpose and have a } \\
\text { corresponding certificate. }\end{array}$ & 2 & - & $\begin{array}{c}0.43 \\
\pm 0.50\end{array}$ & $\begin{array}{c}0.33 \\
\pm 0.47\end{array}$ & $\begin{array}{c}0.39 \\
\pm 0.49\end{array}$ & 0.079 \\
\hline & $\begin{array}{l}\text { Extended services the } \\
\text { pharmacy offers are } \\
\text { documented and stored at } \\
\text { the pharmacy. }\end{array}$ & 2 & - & $\begin{array}{c}0.23 \\
\pm 0.42\end{array}$ & $\begin{array}{c}0.15 \\
\pm 0.36\end{array}$ & $\begin{array}{c}0.20 \\
\pm 0.40\end{array}$ & 0.055 \\
\hline & $\begin{array}{l}\text { During the past two years, } \\
\text { the pharmacists have } \\
\text { offered the service of } \\
\text { measuring health } \\
\text { indicators also outside } \\
\text { the pharmacy. }\end{array}$ & 2 & - & $\begin{array}{c}0.11 \\
\pm 0.31\end{array}$ & $\begin{array}{c}0.09 \\
\pm 0.29\end{array}$ & $\begin{array}{c}0.10 \\
\pm 0.30\end{array}$ & 0.611 \\
\hline & $\begin{array}{l}\text { During the past two years, } \\
\text { the pharmacy has taken } \\
\text { part in health and } \\
\text { environmental campaigns }\end{array}$ & 2 & $\begin{array}{c}0.49 \\
\pm 0.50\end{array}$ & $\begin{array}{l}0.23 \\
\pm 0.42\end{array}$ & $\begin{array}{l}0.16 \\
\pm 0.37\end{array}$ & $\begin{array}{l}0.31 \\
\pm 0.46\end{array}$ & $<0.001$ \\
\hline \multirow{2}{*}{$\begin{array}{l}\text { Provided } \\
\text { extended } \\
\text { services (5) }\end{array}$} & $\begin{array}{l}\text { Blood pressure } \\
\text { is measured. }\end{array}$ & 2 & $\begin{array}{c}0.52 \\
\pm 0.50 \\
\end{array}$ & $\begin{array}{c}0.56 \\
\pm 0.50 \\
\end{array}$ & $\begin{array}{c}0.67 \\
\pm 0.47 \\
\end{array}$ & $\begin{array}{c}0.57 \\
\pm 0.49 \\
\end{array}$ & 0.026 \\
\hline & $\begin{array}{l}\text { Blood sugar level } \\
\text { is measured. }\end{array}$ & 2 & $\begin{array}{c}0.30 \\
\pm 0.46\end{array}$ & $\begin{array}{c}0.23 \\
\pm 0.42\end{array}$ & $\begin{array}{c}0.30 \\
\pm 0.46\end{array}$ & $\begin{array}{c}0.27 \\
\pm 0.45\end{array}$ & 0.215 \\
\hline
\end{tabular}




\begin{tabular}{|c|c|c|c|c|c|c|c|}
\hline & $\begin{array}{l}\text { Total cholesterol level in } \\
\text { blood is measured. }\end{array}$ & 2 & $\begin{array}{c}0.27 \\
\pm 0.45\end{array}$ & $\begin{array}{c}0.19 \\
\pm 0.40\end{array}$ & $\begin{array}{l}0.26 \\
\pm 0.44\end{array}$ & $\begin{array}{c}0.24 \\
\pm 0.43\end{array}$ & 0.113 \\
\hline & $\begin{array}{l}\text { Haemoglobin level in } \\
\text { blood is measured. }\end{array}$ & 2 & - & $\begin{array}{c}0.09 \\
\pm 0.29\end{array}$ & $\begin{array}{c}0.15 \\
\pm 0.36\end{array}$ & $\begin{array}{c}0.12 \\
\pm 0.32\end{array}$ & 0.121 \\
\hline & $\begin{array}{l}\text { Body composition } \\
\text { is analysed. }\end{array}$ & 2 & $\begin{array}{l}0.17 \\
\pm 0.37\end{array}$ & $\begin{array}{c}0.11 \\
\pm 0.31\end{array}$ & $\begin{array}{c}0.19 \\
\pm 0.39\end{array}$ & $\begin{array}{c}0.15 \\
\pm 0.36\end{array}$ & 0.080 \\
\hline \multicolumn{8}{|l|}{$\begin{array}{l}\text { Environment } \\
\text { and } \\
\text { operation }\end{array}$} \\
\hline \multirow{7}{*}{$\begin{array}{l}\text { Conditions } \\
\text { for private } \\
\text { and patient- } \\
\text { centred } \\
\text { coun- } \\
\text { selling (7) }\end{array}$} & $\begin{array}{l}\text { Private counselling while } \\
\text { dispensing prescription } \\
\text { medicines is ensured. }\end{array}$ & 2 & $\begin{array}{c}0.17 \\
\pm 0.37\end{array}$ & $\begin{array}{c}0.15 \\
\pm 0.35\end{array}$ & $\begin{array}{l}0.16 \\
\pm 0.37\end{array}$ & $\begin{array}{c}0.16 \\
\pm 0.01\end{array}$ & 0.854 \\
\hline & $\begin{array}{l}\text { Private counselling while } \\
\text { dispensing OTC medicines } \\
\text { is ensured. }\end{array}$ & 2 & $\begin{array}{c}0.11 \\
\pm 0.31\end{array}$ & $\begin{array}{c}0.09 \\
\pm 0.29\end{array}$ & $\begin{array}{c}0.11 \\
\pm 0.32\end{array}$ & $\begin{array}{c}0.10 \\
\pm 0.31\end{array}$ & 0.839 \\
\hline & $\begin{array}{l}\text { The pharmacy has } \\
\text { a separate room } \\
\text { for counselling. }\end{array}$ & 2 & $\begin{array}{c}0.15 \\
\pm 0.35\end{array}$ & $\begin{array}{c}0.13 \\
\pm 0.33\end{array}$ & $\begin{array}{l}0.16 \\
\pm 0.37\end{array}$ & $\begin{array}{c}0.14 \\
\pm 0.35\end{array}$ & 0.649 \\
\hline & $\begin{array}{l}\text { The customer has a place to } \\
\text { sit while a prescription } \\
\text { medicine is being } \\
\text { dispensed. }\end{array}$ & 2 & $\begin{array}{c}0.62 \\
\pm 0.48\end{array}$ & $\begin{array}{l}0.58 \\
\pm 0.49\end{array}$ & $\begin{array}{c}0.64 \\
\pm 0.48\end{array}$ & $\begin{array}{c}0.61 \\
\pm 0.49\end{array}$ & 0.525 \\
\hline & $\begin{array}{l}\text { The customer has a place to } \\
\text { sit while an OTC medicine } \\
\text { is being dispensed. }\end{array}$ & 2 & $\begin{array}{c}0.49 \\
\pm 0.50\end{array}$ & $\begin{array}{c}0.48 \\
\pm 0.50\end{array}$ & $\begin{array}{c}0.52 \\
\pm 0.50\end{array}$ & $\begin{array}{c}0.50 \\
\pm 0.50\end{array}$ & 0.739 \\
\hline & $\begin{array}{l}\text { The sales room has seats } \\
\text { for customers waiting for } \\
\text { their turn to be serviced. }\end{array}$ & 2 & $\begin{array}{c}0.79 \\
\pm 0.41\end{array}$ & $\begin{array}{c}0.79 \\
\pm 0.41\end{array}$ & $\begin{array}{l}0.80 \\
\pm 0.40\end{array}$ & $\begin{array}{c}0.79 \\
\pm 0.40\end{array}$ & 0.928 \\
\hline & $\begin{array}{l}\text { Drinking water is available } \\
\text { at the pharmacy for the } \\
\text { immediate administration } \\
\text { of a medicine. }\end{array}$ & 2 & $\begin{array}{c}0.81 \\
\pm 0.39\end{array}$ & $\begin{array}{c}0.98 \\
\pm 0.15\end{array}$ & $\begin{array}{l}0.97 \\
\pm 0.17\end{array}$ & $\begin{array}{c}0.91 \\
\pm 0.28\end{array}$ & $<0.001$ \\
\hline \multirow{3}{*}{$\begin{array}{l}\text { Service } \\
\text { provision } \\
\text { supporting } \\
\text { tools (3) }\end{array}$} & $\begin{array}{l}\text { A database of interactions } \\
\text { and adverse drug reactions } \\
\text { is used. }\end{array}$ & 2 & $\begin{array}{l}0.86 \\
\pm 0.35\end{array}$ & $\begin{array}{c}0.82 \\
\pm 0.38\end{array}$ & $\begin{array}{c}0.82 \\
\pm 0.38\end{array}$ & $\begin{array}{l}0.84 \\
\pm 0.37\end{array}$ & 0.566 \\
\hline & $\begin{array}{l}\text { The pharmacy has all tools } \\
\text { for preparing medicines. }\end{array}$ & 2 & $\begin{array}{l}0.53 \\
\pm 0.50 \\
\end{array}$ & $\begin{array}{c}0.89 \\
\pm 0.32 \\
\end{array}$ & $\begin{array}{c}0.86 \\
\pm 0.35 \\
\end{array}$ & $\begin{array}{c}0.72 \\
\pm 0.45 \\
\end{array}$ & $<0.001$ \\
\hline & $\begin{array}{l}\text { All scales and other } \\
\text { measuring instruments } \\
\text { used are calibrated on time. }\end{array}$ & 2 & $\begin{array}{c}0.57 \\
\pm 0.50\end{array}$ & $\begin{array}{c}0.93 \\
\pm 0.26\end{array}$ & $\begin{array}{c}0.85 \\
\pm 0.36\end{array}$ & $\begin{array}{c}0.75 \\
\pm 0.43\end{array}$ & $<0.001$ \\
\hline \multirow[b]{2}{*}{$\begin{array}{l}\text { Procurement } \\
\text { and ensuring } \\
\text { stock (3) }\end{array}$} & $\begin{array}{l}\text { The pharmacy has a system } \\
\text { for monitoring and } \\
\text { supplementing stock. }\end{array}$ & 2 & $\begin{array}{c}0.94 \\
\pm 0.23\end{array}$ & $\begin{array}{c}1.0 \\
\pm 0.07\end{array}$ & $\begin{array}{c}0.84 \\
\pm 0.36\end{array}$ & $\begin{array}{c}0.94 \\
\pm 0.24\end{array}$ & $<0.001$ \\
\hline & $\begin{array}{l}\text { The pharmacy has access to } \\
\text { the lists of unauthorised } \\
\text { medicines that are allowed } \\
\text { to be used upon the request } \\
\text { of professional } \\
\text { associations. }\end{array}$ & 2 & $\begin{array}{l}1.0 \\
\pm 0.00\end{array}$ & $\begin{array}{l}0.98 \\
\pm 0.14\end{array}$ & $\begin{array}{l}0.96 \\
\pm 0.20\end{array}$ & $\begin{array}{l}0.98 \\
\pm 0.13\end{array}$ & 0.013 \\
\hline
\end{tabular}




\begin{tabular}{|c|c|c|c|c|c|c|c|}
\hline & $\begin{array}{l}\text { The pharmacy has a system } \\
\text { for monitoring the expiry } \\
\text { dates of medicines. }\end{array}$ & 2 & - & $\begin{array}{c}1.00 \\
\pm 0.00\end{array}$ & $\begin{array}{c}0.98 \\
\pm 0.14\end{array}$ & $\begin{array}{c}0.99 \\
\pm 0.01\end{array}$ & 0.033 \\
\hline \multirow{5}{*}{$\begin{array}{l}\text { Storage and } \\
\text { dispensing } \\
\text { (5) }\end{array}$} & $\begin{array}{l}\text { The pharmacy has a system } \\
\text { for preventing errors that } \\
\text { can occur while dispensing } \\
\text { medicines. }\end{array}$ & 2 & - & $\begin{array}{c}0.96 \\
\pm 0.20\end{array}$ & $\begin{array}{l}0.92 \\
\pm 0.27\end{array}$ & $\begin{array}{l}0.94 \\
\pm 0.23\end{array}$ & 0.161 \\
\hline & $\begin{array}{l}\text { The pharmacy has } \\
\text { thermoboxes or other } \\
\text { similar means for } \\
\text { dispensing thermolabile } \\
\text { medicines to institutions. }\end{array}$ & 2 & $\begin{array}{c}0.42 \\
\pm 0.49\end{array}$ & $\begin{array}{c}0.53 \\
\pm 0.50\end{array}$ & $\begin{array}{c}0.55 \\
\pm 0.50\end{array}$ & $\begin{array}{c}0.50 \\
\pm 0.50\end{array}$ & 0.029 \\
\hline & $\begin{array}{l}\text { In case of medicines that } \\
\text { require additional steps } \\
\text { before administration, the } \\
\text { pharmacy always offers to } \\
\text { prepare the medicine for } \\
\text { the customer. }\end{array}$ & 2 & $\begin{array}{c}0.92 \\
\pm 0.27\end{array}$ & $\begin{array}{c}0.92 \\
\pm 0.27\end{array}$ & $\begin{array}{c}0.93 \\
\pm 0.26\end{array}$ & $\begin{array}{c}0.92 \\
\pm 0.27\end{array}$ & 0.945 \\
\hline & $\begin{array}{l}\text { The pharmacist advises the } \\
\text { patient (and also the doctor, } \\
\text { if necessary) to apply for } \\
\text { the compensation for the } \\
\text { medicine by way of } \\
\text { exception. }\end{array}$ & 2 & $\begin{array}{c}0.78 \\
\pm 0.42\end{array}$ & $\begin{array}{c}0.79 \\
\pm 0.41\end{array}$ & $\begin{array}{c}0.34 \\
\pm 0.48\end{array}$ & $\begin{array}{c}0.67 \\
\pm 0.47\end{array}$ & $<0.001$ \\
\hline & $\begin{array}{l}\text { Bar code on the package is } \\
\text { used when dispensing the } \\
\text { medicine. }\end{array}$ & 4 & - & $\begin{array}{c}2.75 \\
\pm 0.57\end{array}$ & $\begin{array}{c}2.83 \\
\pm 0.41\end{array}$ & $\begin{array}{c}2.78 \\
\pm 0.51\end{array}$ & 0.170 \\
\hline \multirow{4}{*}{$\begin{array}{l}\text { Quality } \\
\text { management } \\
(4)\end{array}$} & $\begin{array}{l}\text { The pharmacy documents } \\
\text { the complaints it receives } \\
\text { regarding the quality of } \\
\text { medicines. }\end{array}$ & 4 & $\begin{array}{c}2.64 \\
\pm 0.79\end{array}$ & $\begin{array}{c}2.71 \\
\pm 0.65\end{array}$ & $\begin{array}{c}2.70 \\
\pm 0.69\end{array}$ & $\begin{array}{c}2.68 \\
\pm 0.71\end{array}$ & 0.602 \\
\hline & $\begin{array}{l}\text { Prescriptions are } \\
\text { double-checked at the } \\
\text { pharmacy to } \\
\text { discover errors. }\end{array}$ & 4 & $\begin{array}{c}2.32 \\
\pm 0.84\end{array}$ & $\begin{array}{c}2.09 \\
\pm 0.91\end{array}$ & $\begin{array}{c}2.04 \\
\pm 0.88\end{array}$ & $\begin{array}{c}2.16 \\
\pm 0.89\end{array}$ & 0.005 \\
\hline & $\begin{array}{l}\text { Information about local } \\
\text { waste handling options is } \\
\text { available at the pharmacy. }\end{array}$ & 2 & $\begin{array}{c}0.95 \\
\pm 0.22\end{array}$ & $\begin{array}{c}0.85 \\
\pm 0.36\end{array}$ & $\begin{array}{c}0.82 \\
\pm 0.39\end{array}$ & $\begin{array}{c}0.88 \\
\pm 0.33\end{array}$ & $<0.001$ \\
\hline & $\begin{array}{l}\text { The pharmacy has } \\
\text { systemised information on } \\
\text { complaints, quality } \\
\text { problems, recalling of } \\
\text { medicines and other } \\
\text { dispensing limits. }\end{array}$ & 2 & $\begin{array}{c}0.88 \\
\pm 0.32\end{array}$ & $\begin{array}{c}0.97 \\
\pm 0.18\end{array}$ & $\begin{array}{c}0.94 \\
\pm 0.23\end{array}$ & $\begin{array}{c}0.93 \\
\pm 0.25\end{array}$ & 0.003 \\
\hline \multirow{2}{*}{$\begin{array}{l}\text { Management } \\
\text { of customer } \\
\text { relations (6) }\end{array}$} & $\begin{array}{l}\text { All employees of the } \\
\text { pharmacy are aware of and } \\
\text { follow unified principles of } \\
\text { customer service and } \\
\text { problem solving. }\end{array}$ & 2 & $\begin{array}{c}1.0 \\
\pm 0.07\end{array}$ & $\begin{array}{c}0.99 \\
\pm 0.12\end{array}$ & $\begin{array}{c}0.99 \\
\pm 0.01\end{array}$ & $\begin{array}{c}0.99 \\
\pm 0.01\end{array}$ & 0.580 \\
\hline & $\begin{array}{l}\text { Problems related to the } \\
\text { pharmacy service and their } \\
\text { solutions are documented } \\
\text { at the pharmacy. }\end{array}$ & 4 & $\begin{array}{c}2.37 \\
\pm 0.93\end{array}$ & $\begin{array}{c}2.03 \\
\pm 1.10\end{array}$ & $\begin{array}{c}2.13 \\
\pm 1.04\end{array}$ & $\begin{array}{c}2.18 \\
\pm 1.03\end{array}$ & 0.003 \\
\hline
\end{tabular}




\begin{tabular}{|c|c|c|c|c|c|c|c|}
\hline & $\begin{array}{l}\text { To improve the } \\
\text { organisation of work, the } \\
\text { pharmacy manager asks for } \\
\text { feedback and suggestions } \\
\text { from all employees at least } \\
\text { once a year. }\end{array}$ & 2 & $\begin{array}{c}0.85 \\
\pm 0.35\end{array}$ & $\begin{array}{c}0.86 \\
\pm 0.35\end{array}$ & $\begin{array}{c}0.81 \\
\pm 0.40\end{array}$ & $\begin{array}{l}0.84 \\
\pm 0.36\end{array}$ & 0.408 \\
\hline & $\begin{array}{l}\text { The pharmacy has } \\
\text { organized the collection of } \\
\text { feedback (incl. complaints } \\
\text { and suggestions) from } \\
\text { visitors (written, website, } \\
\text { e-mail): }\end{array}$ & 2 & $\begin{array}{c}0.60 \\
\pm 0.49\end{array}$ & $\begin{array}{c}0.73 \\
\pm 0.44\end{array}$ & $\begin{array}{c}0.72 \\
\pm 0.45\end{array}$ & $\begin{array}{l}0.68 \\
\pm 0.47\end{array}$ & 0.005 \\
\hline & $\begin{array}{l}\text { During the past three years, } \\
\text { the pharmacy has carried } \\
\text { out a satisfaction survey } \\
\text { among its customers }\end{array}$ & 2 & - & $\begin{array}{c}0.09 \\
\pm 0.29\end{array}$ & $\begin{array}{c}0.36 \\
\pm 0.48\end{array}$ & $\begin{array}{c}0.20 \\
\pm 0.40\end{array}$ & $<0.001$ \\
\hline & $\begin{array}{l}\text { All pharmacy employees } \\
\text { engaged in customer } \\
\text { service are proficient } \\
\text { in Estonian. }\end{array}$ & 2 & $\begin{array}{c}0.97 \\
\pm 0.17\end{array}$ & $\begin{array}{c}0.96 \\
\pm 0.19\end{array}$ & $\begin{array}{l}0.97 \\
\pm 0.17\end{array}$ & $\begin{array}{c}0.97 \\
\pm 0.18\end{array}$ & 0.843 \\
\hline \multirow{2}{*}{$\begin{array}{l}\text { Personnel } \\
\text { management } \\
\text { (2) }\end{array}$} & $\begin{array}{l}\text { The pharmacy has } \\
\text { approved the principles of } \\
\text { personnel management } \\
\text { listed in CPSQG }\end{array}$ & 4 & $\begin{array}{l}2.37 \\
\pm 0.71\end{array}$ & $\begin{array}{c}2.33 \\
\pm 0.78\end{array}$ & $\begin{array}{c}2.51 \\
\pm 0.65\end{array}$ & $\begin{array}{c}2.39 \\
\pm 0.73\end{array}$ & 0.061 \\
\hline & $\begin{array}{l}\text { The pharmacy has enough } \\
\text { employees to ensure a } \\
\text { quality pharmacy service, } \\
\text { including thorough } \\
\text { counselling (considering } \\
\text { different times of day and } \\
\text { month). }\end{array}$ & 4 & $\begin{array}{c}2.27 \\
\pm 0.63\end{array}$ & $\begin{array}{c}2.19 \\
\pm 0.74\end{array}$ & $\begin{array}{c}2.02 \\
\pm 0.72\end{array}$ & $\begin{array}{l}2.18 \\
\pm 0.70\end{array}$ & 0.005 \\
\hline \multirow{4}{*}{$\begin{array}{l}\text { Manager's re- } \\
\text { sponsibilities } \\
\text { (4) }\end{array}$} & $\begin{array}{l}\text { The pharmacy manager } \\
\text { performs all duties listed in } \\
\text { CPSQG. }\end{array}$ & 4 & $\begin{array}{c}2.61 \\
\pm 0.53 \\
\end{array}$ & $\begin{array}{c}2.68 \\
\pm 0.50 \\
\end{array}$ & $\begin{array}{c}2.56 \\
\pm 0.62 \\
\end{array}$ & $\begin{array}{c}2.63 \\
\pm 0.54 \\
\end{array}$ & 0.109 \\
\hline & $\begin{array}{l}\text { The pharmacy has a } \\
\text { development plan. }\end{array}$ & 2 & - & $\begin{array}{c}0.48 \\
\pm 0.50\end{array}$ & $\begin{array}{c}0.37 \\
\pm 0.48\end{array}$ & $\begin{array}{l}0.44 \\
\pm 0.50 \\
\end{array}$ & 0.034 \\
\hline & $\begin{array}{l}\text { The pharmacy manager } \\
\text { discusses the results of } \\
\text { internal audit with all } \\
\text { employees. }\end{array}$ & 2 & $\begin{array}{c}0.95 \\
\pm 0.23\end{array}$ & $\begin{array}{c}0.93 \\
\pm 0.26\end{array}$ & $\begin{array}{c}0.91 \\
\pm 0.29\end{array}$ & $\begin{array}{c}0.93 \\
\pm 0.25\end{array}$ & 0.386 \\
\hline & $\begin{array}{l}\text { The pharmacy manager is } \\
\text { familiar with the } \\
\text { accounting of the } \\
\text { pharmacy. }\end{array}$ & 2 & $\begin{array}{c}0.93 \\
\pm 0.25\end{array}$ & $\begin{array}{c}0.92 \\
\pm 0.27\end{array}$ & $\begin{array}{c}0.82 \\
\pm 0.39\end{array}$ & $\begin{array}{c}0.90 \\
\pm 0.30\end{array}$ & 0.001 \\
\hline \multirow{2}{*}{$\begin{array}{l}\text { Internal com- } \\
\text { munication } \\
\text { (3) }\end{array}$} & $\begin{array}{l}\text { The pharmacy has a } \\
\text { designated place for } \\
\text { disseminating written } \\
\text { information (e.g., billboard, } \\
\text { web environment). }\end{array}$ & 2 & $\begin{array}{c}0.85 \\
\pm 0.35\end{array}$ & $\begin{array}{c}0.89 \\
\pm 0.32\end{array}$ & $\begin{array}{c}0.89 \\
\pm 0.31\end{array}$ & $\begin{array}{c}0.88 \\
\pm 0.33\end{array}$ & 0.462 \\
\hline & $\begin{array}{l}\text { The pharmacists are aware } \\
\text { of medicine shortages, } \\
\text { delivery times and delivery } \\
\text { channels. }\end{array}$ & 4 & $\begin{array}{c}2.54 \\
\pm 0.50\end{array}$ & $\begin{array}{c}2.45 \\
\pm 0.51\end{array}$ & $\begin{array}{c}2.52 \\
\pm 0.50\end{array}$ & $\begin{array}{c}2.49 \\
\pm 0.51\end{array}$ & 0.028 \\
\hline
\end{tabular}




\begin{tabular}{|c|c|c|c|c|c|c|c|}
\hline & $\begin{array}{l}\text { The pharmacy has a } \\
\text { functioning system for } \\
\text { disseminating important } \\
\text { information on } \\
\text { medicines/treatment } \\
\text { methods as well as } \\
\text { information acquired } \\
\text { during training courses } \\
\text { among colleagues. }\end{array}$ & 2 & $\begin{array}{c}0.76 \\
\pm 0.43\end{array}$ & $\begin{array}{c}0.73 \\
\pm 0.44\end{array}$ & $\begin{array}{c}0.73 \\
\pm 0.44\end{array}$ & $\begin{array}{c}0.74 \\
\pm 0.44\end{array}$ & 0.832 \\
\hline \multirow{7}{*}{$\begin{array}{l}\text { External } \\
\text { Communica- } \\
\text { tion } \\
(7)\end{array}$} & $\begin{array}{l}\text { If a customer needs to be } \\
\text { sent to another pharmacy } \\
\text { for a medicine, the } \\
\text { pharmacist first agrees on } \\
\text { that with the other } \\
\text { pharmacy. }\end{array}$ & 4 & $\begin{array}{c}2.11 \\
\pm 0.762\end{array}$ & $\begin{array}{c}2.17 \\
\pm 0.69\end{array}$ & $\begin{array}{c}2.30 \\
\pm 0.61\end{array}$ & $\begin{array}{l}2.18 \\
\pm 0.70\end{array}$ & 0.051 \\
\hline & $\begin{array}{l}\text { If substance abuse or poor } \\
\text { medication adherence can } \\
\text { be suspected, the } \\
\text { pharmacist contacts the } \\
\text { doctor, nurse, or social } \\
\text { worker. }\end{array}$ & 4 & $\begin{array}{c}2.11 \\
\pm 0.93\end{array}$ & $\begin{array}{c}1.98 \\
\pm 0.98\end{array}$ & $\begin{array}{c}1.77 \\
\pm 0.94\end{array}$ & $\begin{array}{l}1.97 \\
\pm 0.956\end{array}$ & 0.006 \\
\hline & $\begin{array}{l}\text { The prescriber shall be } \\
\text { notified if he/she has } \\
\text { mistaken the requirements } \\
\text { of the prescription } \\
\text { procedure. }\end{array}$ & 4 & $\begin{array}{l}2.56 \\
\pm 0.67\end{array}$ & $\begin{array}{c}2.57 \\
\pm 0.64\end{array}$ & $\begin{array}{c}2.47 \\
\pm 0.70\end{array}$ & $\begin{array}{c}2.54 \\
\pm 0.67\end{array}$ & 0.344 \\
\hline & $\begin{array}{l}\text { The pharmacy forwards } \\
\text { medicine-related relevant } \\
\text { information, including that } \\
\text { about shortages and } \\
\text { cheaper medicines, to its } \\
\text { cooperation partners. }\end{array}$ & 4 & $\begin{array}{l}1.96 \\
\pm 0.84\end{array}$ & $\begin{array}{c}2.03 \\
\pm 0.82\end{array}$ & $\begin{array}{c}2.03 \\
\pm 0.93\end{array}$ & $\begin{array}{c}2.00 \\
\pm 0.86\end{array}$ & 0.632 \\
\hline & $\begin{array}{l}\text { The State Agency of } \\
\text { Medicines is informed of } \\
\text { problems related to the } \\
\text { supply of medicines }\end{array}$ & 4 & $\begin{array}{l}1.20 \\
\pm 1.01\end{array}$ & $\begin{array}{l}1.13 \\
\pm 0.97\end{array}$ & $\begin{array}{c}0.97 \\
\pm 0.92\end{array}$ & $\begin{array}{c}1.11 \\
\pm 0.97\end{array}$ & 0.104 \\
\hline & $\begin{array}{l}\text { The data about the } \\
\text { pharmacists and assistant } \\
\text { pharmacists of the } \\
\text { pharmacy is forwarded to } \\
\text { the registry of the Health } \\
\text { Board on time. }\end{array}$ & 2 & $\begin{array}{l}1.00 \\
\pm 0.00\end{array}$ & $\begin{array}{c}1.00 \\
\pm 0.07\end{array}$ & $\begin{array}{l}1.00 \\
\pm 0.00\end{array}$ & $\begin{array}{c}1.00 \\
\pm 0.04\end{array}$ & 0.441 \\
\hline & $\begin{array}{l}\text { The pharmacists' } \\
\text { involvement in the } \\
\text { development of } \\
\text { professional and } \\
\text { organisational activities. }\end{array}$ & 4 & - & $\begin{array}{c}1.59 \\
\pm 0.91\end{array}$ & $\begin{array}{l}1.38 \\
\pm 0.95\end{array}$ & $\begin{array}{c}1.51 \\
\pm 0.93\end{array}$ & 0.043 \\
\hline $\begin{array}{l}\text { Communication } \\
\text { obligation (2) }\end{array}$ & $\begin{array}{l}\text { If a wrong medicine has } \\
\text { been dispensed or this can } \\
\text { be suspected, the } \\
\text { pharmacist immediately } \\
\text { contacts the patient and/or } \\
\text { the doctor. }\end{array}$ & 4 & $\begin{array}{c}2.98 \\
\pm 0.21\end{array}$ & $\begin{array}{l}2.98 \\
\pm 0.17\end{array}$ & $\begin{array}{c}2.99 \\
\pm 0.12\end{array}$ & $\begin{array}{c}2.98 \\
\pm 0.17\end{array}$ & 0.863 \\
\hline
\end{tabular}




\begin{tabular}{|c|c|c|c|c|c|c|c|}
\hline & $\begin{array}{l}\text { If substance abuse can be } \\
\text { suspected, the pharmacist } \\
\text { informs the State Agency } \\
\text { of Medicines (in case of } \\
\text { psychotropic or narcotic } \\
\text { medicines) and/or } \\
\text { the doctor. }\end{array}$ & 4 & $\begin{array}{c}2.65 \\
\pm 0.72\end{array}$ & $\begin{array}{c}2.46 \\
\pm 0.91\end{array}$ & $\begin{array}{c}2.37 \\
\pm 0.90\end{array}$ & $\begin{array}{c}2.51 \\
\pm 0.85\end{array}$ & 0.006 \\
\hline $\begin{array}{l}\text { Pharmacist } \\
\text { as a lecturer } \\
\text { and author of } \\
\text { articles (1) }\end{array}$ & $\begin{array}{l}\text { The pharmacists have } \\
\text { made a professional } \\
\text { presentation or written an } \\
\text { article within the past } \\
\text { three years }\end{array}$ & 2 & $\begin{array}{c}0.23 \\
\pm 0.42\end{array}$ & $\begin{array}{c}0.22 \\
\pm 0.42\end{array}$ & $\begin{array}{c}0.28 \\
\pm 0.45\end{array}$ & $\begin{array}{c}0.25 \\
\pm 0.43\end{array}$ & 0.483 \\
\hline \multirow{6}{*}{$\begin{array}{l}\text { Pharmacists' } \\
\text { lifelong } \\
\text { learning (6) }\end{array}$} & $\begin{array}{l}\text { Information about training } \\
\text { opportunities reaches all } \\
\text { pharmacists. }\end{array}$ & 4 & $\begin{array}{c}2.82 \\
\pm 0.43\end{array}$ & $\begin{array}{c}2.89 \\
\pm 0.32\end{array}$ & $\begin{array}{c}2.89 \\
\pm 0.34\end{array}$ & $\begin{array}{c}2.86 \\
\pm 0.37\end{array}$ & 0.121 \\
\hline & $\begin{array}{l}\text { All pharmacists have equal } \\
\text { opportunities to attend } \\
\text { training courses. }\end{array}$ & 4 & $\begin{array}{c}2.71 \\
\pm 0.56\end{array}$ & $\begin{array}{c}2.87 \\
\pm 0.37\end{array}$ & $\begin{array}{c}2.83 \\
\pm 0.49\end{array}$ & $\begin{array}{c}2.80 \\
\pm 0.48\end{array}$ & 0.003 \\
\hline & $\begin{array}{l}\text { Each employee has a } \\
\text { training card at the } \\
\text { pharmacy. }\end{array}$ & 2 & $\begin{array}{c}0.35 \\
\pm 0.48 \\
\end{array}$ & $\begin{array}{c}0.94 \\
\pm 0.24 \\
\end{array}$ & $\begin{array}{c}0.93 \\
\pm 0.26 \\
\end{array}$ & $\begin{array}{c}0.72 \\
\pm 0.45\end{array}$ & $<0.001$ \\
\hline & $\begin{array}{l}\text { Each employee's training } \\
\text { needs are identified at least } \\
\text { once a year. }\end{array}$ & 2 & $\begin{array}{c}0.61 \\
\pm 0.49\end{array}$ & $\begin{array}{c}0.94 \\
\pm 0.23\end{array}$ & $\begin{array}{l}0.95 \\
\pm 0.22\end{array}$ & $\begin{array}{c}0.82 \\
\pm 0.38\end{array}$ & $<0.001$ \\
\hline & $\begin{array}{l}\text { The pharmacy has ensured } \\
\text { access to essential sources } \\
\text { of information. }\end{array}$ & 2 & $\begin{array}{c}0.99 \\
\pm 0.10\end{array}$ & $\begin{array}{l}1.00 \\
\pm 0.07\end{array}$ & $\begin{array}{c}1.0 \\
\pm 0.00\end{array}$ & $\begin{array}{c}0.99 \\
\pm 0.07\end{array}$ & 0.471 \\
\hline & $\begin{array}{l}\text { Information sources are } \\
\text { used regularly. }\end{array}$ & 4 & $\begin{array}{c}2.84 \\
\pm 0.38\end{array}$ & $\begin{array}{c}2.60 \\
\pm 0.82 \\
\end{array}$ & $\begin{array}{c}2.40 \\
\pm 0.62\end{array}$ & $\begin{array}{c}2.64 \\
\pm 0.66\end{array}$ & $<0.001$ \\
\hline \multirow{4}{*}{$\begin{array}{l}\text { Pharmacy as } \\
\text { a traineeship } \\
\text { institution (4) }\end{array}$} & $\begin{array}{l}\text { The pharmacy has hosted a } \\
\text { trainee at least once within } \\
\text { the past three years. }\end{array}$ & 2 & $\begin{array}{c}0.32 \\
\pm 0.47\end{array}$ & $\begin{array}{c}0.35 \\
\pm 0.48 \\
\end{array}$ & $\begin{array}{c}0.43 \\
\pm 0.50\end{array}$ & $\begin{array}{c}0.36 \\
\pm 0.48\end{array}$ & 0.133 \\
\hline & $\begin{array}{l}\text { The pharmacy provides all } \\
\text { pharmacy services listed in } \\
\text { CPSQG. }\end{array}$ & 2 & $\begin{array}{l}0.54 \\
\pm 0.50\end{array}$ & $\begin{array}{c}0.44 \\
\pm 0.50\end{array}$ & $\begin{array}{c}0.47 \\
\pm 0.50\end{array}$ & $\begin{array}{c}0.49 \\
\pm 0.50\end{array}$ & 0.174 \\
\hline & $\begin{array}{l}\text { The organisation of work } \\
\text { of the pharmacy ensures } \\
\text { that a supervisor monitors } \\
\text { the trainee's work. }\end{array}$ & 2 & $\begin{array}{l}0.78 \\
\pm 0.42\end{array}$ & $\begin{array}{l}0.68 \\
\pm 0.47\end{array}$ & $\begin{array}{c}0.77 \\
\pm 0.42\end{array}$ & $\begin{array}{c}0.74 \\
\pm 0.44\end{array}$ & 0.074 \\
\hline & $\begin{array}{l}\text { During the traineeship } \\
\text { period at the pharmacy, } \\
\text { pharmacists communicate } \\
\text { with students to identify } \\
\text { their level of knowledge } \\
\text { and organise the rest of the } \\
\text { traineeship period. }\end{array}$ & 4 & $\begin{array}{c}2.07 \\
\pm 1.24\end{array}$ & $\begin{array}{c}1.89 \\
\pm 1.40\end{array}$ & $\begin{array}{c}2.14 \\
\pm 1.24\end{array}$ & $\begin{array}{c}2.04 \\
\pm 1.29\end{array}$ & 0.232 \\
\hline $\begin{array}{l}\text { Compliance } \\
\text { with legal } \\
\text { requirements } \\
\text { (4) }\end{array}$ & $\begin{array}{l}\text { The pharmacy's email } \\
\text { address is in the mailing } \\
\text { lists of the Ministry of } \\
\text { Social Affairs, the State } \\
\text { Agency of Medicines, and } \\
\text { the Estonian Health } \\
\text { Insurance Fund }\end{array}$ & 2 & $\begin{array}{c}1.0 \\
\pm 0.07\end{array}$ & $\begin{array}{c}0.99 \\
\pm 0.10\end{array}$ & $\begin{array}{c}0.97 \\
\pm 0.17\end{array}$ & $\begin{array}{c}0.99 \\
\pm 0.11\end{array}$ & 0.137 \\
\hline
\end{tabular}




\begin{tabular}{|c|c|c|c|c|c|c|}
\hline $\begin{array}{l}\text { All pharmacists know how } \\
\text { to find information and } \\
\text { legal acts on the home } \\
\text { pages of Riigi Teataja, the } \\
\text { State Agency of Medicines, } \\
\text { the Ministry of Social } \\
\text { Affairs, the Estonian } \\
\text { Health Insurance Fund, etc. }\end{array}$ & 2 & $\begin{array}{c}0.97 \\
\pm 0.18\end{array}$ & $\begin{array}{c}0.98 \\
\pm 0.15\end{array}$ & $\begin{array}{c}0.96 \\
\pm 0.20\end{array}$ & $\begin{array}{c}0.97 \\
\pm 0.18\end{array}$ & 0.609 \\
\hline $\begin{array}{l}\text { Information on all } \\
\text { important amendments } \\
\text { regarding pharmacy work } \\
\text { reaches all employees. }\end{array}$ & 4 & $\begin{array}{c}2.94 \\
\pm 0.42\end{array}$ & $\begin{array}{c}2.91 \\
\pm 0.29\end{array}$ & $\begin{array}{c}2.90 \\
\pm 0.30\end{array}$ & $\begin{array}{c}2.92 \\
\pm 0.34\end{array}$ & 0.491 \\
\hline $\begin{array}{l}\text { The pharmacists are } \\
\text { well-informed of changes } \\
\text { in the reference prices and } \\
\text { price agreements of } \\
\text { medicines. The cheapest } \\
\text { proprietary medicine of the } \\
\text { same active substance is } \\
\text { available at the pharmacy. }\end{array}$ & 4 & - & $\begin{array}{c}2.78 \\
\pm 0.42\end{array}$ & $\begin{array}{c}2.82 \\
\pm 0.39\end{array}$ & $\begin{array}{c}2.79 \\
\pm 0.41\end{array}$ & 0.389 \\
\hline
\end{tabular}

\section{References}

1. Pharmaceutical Group of European Union. Pharmacy: A Vision for Community. Belgium. Available online: https://www. pgeu.eu/wp-content/uploads/2019/04/Pharmacy-2030_-A-Vision-for-Community-Pharmacy-in-Europe.pdf (accessed on 17 June 2021).

2. Murray, R. Community Pharmacy Clinical Services Review; NHS: London, UK, 2016; Available online: https:/ / www.england.nhs. uk/commissioning/wp-content/uploads/sites/12/2016/12/community-pharm-clncl-serv-rev.pdf (accessed on 5 May 2021).

3. International Pharmaceutical Federation. Pharmacy at a Glance-2015-2017; International Pharmaceutical Federation: The Hague, The Netherlands, 2017.

4. World Health Organization, Regional Office for Europe. The Legal and Regulatory Framework for Community Pharmacies in the WHO European Region; World Health Organization, Regional Office for Europe: Copenhagen, Denmark, 2019; Available online: https: / / apps.who.int/iris/handle/10665/326394 (accessed on 18 June 2021).

5. OECD. Realising the Potential of Primary Health Care, OECD Health Policy Studies; OECD Publishing: Paris, France, 2020. [CrossRef]

6. Good Pharmacy Practice in Community and Hospital Pharmacy Settings; World Health Organization (WHO) Technical Report Series, No. 885, Annex 7; WHO: Geneva, Switzerland, 1999; Available online: https:/ /www.who.int/publications/i/item/WHO_TRS_ 885 (accessed on 18 June 2021).

7. World Health Organization. Joint FIP/WHO Guidelines on Good Pharmacy Practice: Standards for Quality of Pharmacy Services; WHO: Geneva, Switzerland, 2011; Available online: https://www.who.int/medicines/areas/quality_safety/quality_assurance/ FIPWHOGuidelinesGoodPharmacyPracticeTRS961Annex8.pdf (accessed on 17 June 2021).

8. Ravimiamet [State Agency of Medicines]. Apteegistatistika [Pharmacy Statistics]. Available online: https://sam.ee/ apteegistatistika?group=5 (accessed on 5 January 2021).

9. Statistics Estonia. Available online: https:/ / www.stat.ee/en (accessed on 17 June 2021).

10. Pharmaceutical Group of European Union. European Community Pharmacy Sector Facts E Figures, PGEU Database 2016-2017; Pharmaceutical Group of the European Union: Brussels, Belgium, 2018.

11. Volmer, D.; Sepp, K.; Raal, A.; Atkinson, J. Pharmacy practice and education in Estonia. Pharmacy 2019, 7, 87. [CrossRef]

12. Sepp, K.; Koppel, A.; Volmer, D. Apteegiteenuse kvaliteedijuhise rakendamine Eesti üldapteekides 2014-19 [Implementation of Community Pharmacy Service Quality Guidelines in Estonia 2014-19]. Apteek Täna 2020, 11, 83-94.

13. Saapar, M. Apteegi roll suitsetamisest loobumisel [Community pharmacy role in providing smoking cessation service]. Apteek Täna 2019, 3, 18-19.

14. Sepp, K.; Kukk, C.; Cavaco, A.; Volmer, D. How involvement of community pharmacies improves accessibility to and awareness about flu vaccination?-An example from Estonia. Expert Rev. Vaccines 2020, 19, 983-990. [CrossRef] [PubMed]

15. Tuula, A.; Randmäe, L. Implementing New Pharmacy Service-Medication Use Review. How Are We Doing? New Chapter in Patient Care: Medication Use Review in the Era of Digital Care, Narva-Jõesuu, Estonia. November 2019. Available online: https:/ /ncpc2019.erpmusic.com/materials/Presentation\%20NCPC\%202019\%20EST.pdf (accessed on 18 June 2021).

16. Eesti Apteekide Ühendus [Estonian Pharmacies Association]. Apteegiteenuse Kvaliteedijuhis [Community Pharmacy Service Quality Guidelines]. Available online: https://www.ravimiamet.ee/sites/default/files/documents/publications/ apteegiteenuse_kvaliteedijuhis_2016/apteegiteenuse_kvaliteedijuhis_2016.html (accessed on 10 December 2020). 
17. Medicinal Product Act. RT I 2005, 2, 4. Available online: https://www.riigiteataja.ee/en/eli/ee/525112013005/consolide/current (accessed on 18 January 2021).

18. Blenkinsopp, A.; Bond, C.; Celino, G.; Inch, J.; Gray, N. National Evaluation of the New Community Pharmacy Contract; Pharmacy Practice Research Trust: London, UK, 2009; ISBN 9780955696985.

19. American Society of Health-System Pharmacists. ASHP Guidelines. Available online: https://www.ashp.org/PharmacyPractice/Policy-Positions-and-Guidelines/Browse-by-Document-Type/Guidelines?loginreturnUrl=SSOCheckOnly (accessed on 10 January 2021).

20. Pharmaceutical Society of Australia. Professional Practice Standards-Version 4-June 2010. Pharmaceutical Society of Australia, 2010. Available online: https:/ / www.slideshare.net/boriscvijic1/professional-practicestandardsv4 (accessed on 17 June 2021).

21. Langley, G.L.; Moen, R.; Nolan, K.M.; Nolan, T.W.; Norman, C.L.; Provost, L.P. The Improvement Guide: A Practical Approach to Enhancing Organisational Performance, 2nd ed.; Jossey-Bass Publishers: San Francisco, CA, USA, 2009; ISBN 978-0-470-19241-2.

22. Lenbaum, K. Apteegiteenuse Kvaliteedijuhise Väljatöotamine ja Rakendamine Eesti Üldapteekides [Community Pharmacy Service Quality Guidelines Development and Implementation in Community Pharmacies in Estonia]; Proviisoriõppe uurimistöö, Meditsiiniteaduste valdkond, Tartu Ülikool: Tartu, Estonia, 2014.

23. Meditsiiniuudised [Medicinal News]. Apteekri Roll Tervishoiusüsteemis Suureneb [Community Pharmacist's Role in Healthcare System Increases]. 19 February 2019. Available online: https://www.mu.ee/uudised/2019/02/19/apteekri-rolltervishoiususteemis-suureneb-22 (accessed on 15 May 2021).

24. Beauchamp, T.L. The "Four Principles" Approach to Health Care Ethics. In Principles of Health Care Ethics, 2nd ed.; Ashcroft, R.E., Dawson, A., Draper, H., McMillan, J.R., Eds.; John Wiley \& Sons Ltd.: Chichester, UK, 2015; pp. 3-12.

25. World Medical Association. WMA Declaration of Helsinki-Ethical Principles for Medical Research Involving Human Subjects; World Medical Association: Ferney-Voltaire, France, 2013; Available online: https://www.wma.net/policies-post/wma-declaration-ofhelsinki-ethical-principles-for-medical-research-involving-human-subjects/ (accessed on 18 June 2021).

26. Riigikogu [Parliament]. Personal Data Protection Act; Riigi Teataja: Estonia, 2019; Available online: https://www.riigiteataja.ee/ en/eli/523012019001/consolide (accessed on 24 June 2021).

27. Mossialos, E.; Mrazek, M.; Walley, T. (Eds.) Regulating Pharmaceuticals in Europe: Striving for Efficiency, Equity, and Quality; Open University Press: Maidenhead, UK, 2004.

28. Almarsdottir, A.B.; Morgall Traulsen, J. Multimethod research into policy change in the pharmacy sector-The Nordic case. Res. Soc. Adm. Pharm. 2009, 5, 82-90. [CrossRef]

29. Employed Community Pharmacists in Europe (EphEU). Poland-More about Pharmacy. Available online: https://epheu.eu/ poland-more-about-pharmacy / (accessed on 17 June 2021).

30. Petkova, V.; Georgiev, S.; Dimitrova, Z.L.; Radivoeva, M. Implementation of pharmaceutical care knowledge in Bulgarian community pharmacies. Pharm. Educ. 2006, 6, 107-110. [CrossRef]

31. Nastaravičius, A.; Ramanauskienè, K. Role of a Community Pharmacy Service in Care of Bronchial Asthma Patients in Lithuania. Can. Respir. J. 2018, 2018, 6060581. [CrossRef]

32. Rupp, M.T. Assessing Quality of Care in Pharmacy: Remembering Donabedian. J. Manag. Care Spec. Pharm. 2018, 24, 354-356. [CrossRef] [PubMed]

33. Donabedian, A. Quality assessment and monitoring. Retrospect and prospect. Eval. Health Prof. 1983, 6, 363-375. [CrossRef]

34. Campbell, S.M.; Braspenning, J.; Hutchinson, A.; Marshall, M. Research methods used in developing and applying quality indicators in primary care. BMJ 2003, 2226, 816-819. [CrossRef]

35. Volmer, D.; Lilja, J.; Hamilton, D. How well informed are pharmacy customers in Estonia about minor illnesses and over-thecounter medicines. Medicina 2007, 43, 70. [CrossRef]

36. Jänese, J. IT Tools in Dispensing and Counselling of Medicines in e-Estonia. New Chapter in Patient Care: Medication Use Review in the Era of Digital Care, Narva-Jõesuu, Estonia. November 2019. Available online: https:/ /ncpc2019.erpmusic.com/materials/ Presentation\%20J.\%20J\%C3\%A4nese.pdf (accessed on 18 June 2021).

37. Shoemaker, S.J.; Ramalho de Oliveira, D.; Alves, M.; Ekstrand, M. The medication experience: Preliminary evidence of its value for patient education and counselling on chronic medications. Patient Educ. Couns. 2011, 83, 443-450. [CrossRef] [PubMed]

38. Sepp, K.; Ventmann, I.; Raal, A.; Volmer, D. Apteeker on hinnatud ja oluline spetsialist patsiendi tervise tagamisel [A pharmacist is a valued and important specialist in ensuring the health of a patient]. Apteeker 2017, 10, 2-4. Available online: https://www. med24.ee/ajakirjad/apteeker/oktoober-2017/apteeker-hinnatud-ja-oluline-spetsialist-patsiendi-tervise?lang=en-gb (accessed on 12 May 2021).

39. Volmer, D.; Bell, J.S.; Janno, R.; Raal, A.; Hamilton, D.D.; Airaksinen, M.S. Change in public satisfaction with community pharmacy services in Tartu, Estonia, between 1993 and 2005. Res. Soc. Adm. Pharm. 2009, 5, 337-346. [CrossRef] [PubMed]

40. Habicht, T.; Reinap, M.; Kasekamp, K.; Sikkut, R.; Aaben, L.; Van Ginneken, E. Estonia: Health system review. Health Syst. Transit. 2018, 20, 1-193. Available online: https:/ /apps.who.int/iris/bitstream/handle/10665/330201/HiT-20-1-2018-eng.pdf (accessed on 18 June 2021).

41. Goundrey-Smith, S. Examining the role of new technology in pharmacy: Now and in the future. Pharm. J. 2014, 2. Available online: https: / / pharmaceutical-journal.com/article/news/examining-the-role-of-new-technology-in-pharmacy-now-and-inthe-future (accessed on 15 March 2021). [CrossRef] 
42. e-Estonia. E-Solutions in Healthcare. Available online: https:/ / e-estonia.com/solutions/healthcare/ (accessed on 8 January 2021).

43. Pharmaceutical Group of European Union. PGEU Medicine Shortages Survey 2019 Results. 2020. Available online: https: / / www.pgeu.eu/wp-content/uploads /2019/03/PGEU-Medicine-Shortages-Survey-Results-2019-1.pdf (accessed on 15 May 2021).

44. Cipolle, R.J.; Strand, L.; Morley, P. Pharmaceutical Care Practice the Patient Centered Approach to Medication Management, 3rd ed.; McGraw Hill: New York, NY, USA, 2012.

45. Micallef, R.; Kayyali, R. A Systematic Review of Models Used and Preferences for Continuing Education and Continuing Professional Development of Pharmacists. Pharmacy 2019, 7, 154. [CrossRef]

46. Dopp, A.L.; Moulton, J.R.; Rouse, M.J.; Trewet, C.B. A five-state continuing professional development pilot program for practicing pharmacists. Am. J. Pharm. Educ. 2010, 74, 28. [CrossRef]

47. Eesti Farmaatsia Selts [Estonian Pharmaceutical Society]. Apteegisektori Visioonidokument Aastani 2030: Patsiendikeskne Tervishoiuteenus-Võti Tulevikku [Vision Document for the Pharmacy Sector until 2030: Patient-Centered Healthcare-The Key to the Future]. 17 March 2021. Available online: http:/ / efs.ee/wp-content/uploads/Apteegisektori-visioonidokument-aastani2030.pdf (accessed on 15 May 2021).

48. Kivimets, K. Kahjude vähendamise teenusega on Tartu Raekoja apteegis tehtud edukas algus [The harm reduction service has got off to a successful start in the Tartu Town Hall pharmacy]. Apteek Täna 2020, 3, 20-21.

49. Sepp, K.; Tuula, A.; Bobrova, V.; Volmer, D. Primary health care policy and vision for community pharmacy and pharmacists in Estonia. Pharm. Pract. 2021, 19, 2404. [CrossRef]

50. Rass, H.; Lubi, K.; Sepp, K.; Volmer, D. Kriisiolukorra mõju Eesti apteekide ja apteekrite tegevusele COVID-19 pandeemia näitel [Impact of the crisis situation on the activities of Estonian pharmacies and pharmacists on the example of the COVID-19 pandemic]. Apteek Täna 2021, 1, 62-72.

51. Huisman, E.R.; Morales, E.; van Hoof, J.; Kort, H.S. Healing environment: A review of the impact of physical environmental factors on users. Build. Environ. 2012, 58, 70-80. [CrossRef]

52. Anderson, C.; Blenkinsopp, B. Community pharmacy supply of emergency hormonal contraception: A structured literature review of international evidence. Hum. Reprod. 2006, 21, 272-284. [CrossRef] [PubMed]

53. Kantar Emor. Eesti Elanike Hinnangud Tervisele ja Arstiabile [Estonian Residents' Assessments of Health and Medical Care]. Tallinn. 2020. Available online: https://www.haigekassa.ee/haigekassa/eesti-haigekassa/uuringud-ja-analuusid (accessed on 15 January 2021).

54. World Health Organization. Review of the Estonian Pharmaceutical Sector: Towards the Development of a National Medicines Policies. 2009. Available online: https://apps.who.int/iris/bitstream/handle/10665/107271/E93049.pdf?sequence=1\& isAllowed =y (accessed on 4 April 2021).

55. Sotsiaalministeerium [Ministry of Social Affairs]. Faktileht: Apteegireform [Fact Sheet: Pharmacy Ownership]. Available online: https://www.sm.ee/sites/default/files/news-related-files/faktileht_apteegireform_2608.pdf (accessed on 15 January 2021).

56. Ravimiamet [State Agency of Medicines]. Ülevaade Apteekidest 2020 Aasta Apteegireformi ja Eriolukorra Valguses [The State Agency of Medicines' Overview of Pharmacies in the Light of the 2020 Pharmacy Reform and the Extraordinary Situation Due to COVID-19]. October 2020. Available online: https://www.ravimiamet.ee/ravimiameti-\%C3\%BClevaade-apteekidest-2020-aastaapteegireformi-ja-eriolukorra-valguses (accessed on 6 January 2021).

57. Jackson, J.; Urick, B. Performance-based pharmacy payment models: The case for change. Aust. Health Rev. 2019, 43, 502-507. [CrossRef]

58. Doucette, W.R.; McDonough, R.P.; Herald, F.; Goedken, A.; Funk, J.; Deninger, M.J. Pharmacy performance while providing continuous medication monitoring. J. Am. Pharm. Assoc. 2017, 56, 692-697. [CrossRef] [PubMed]

59. Canadian Pharmacists Association. A Review of Pharmacy Services in Canada and the Health and Economic Evidence. Available online: https: / www.pharmacists.ca/cpha-ca/assets/File/cpha-on-the-issues/Pharmacy\%20Services\%20Report\% 201.pdf (accessed on 7 April 2021).

60. Healthcare for Internationals. Cost of Medication and Service Fees. Available online: https://h4i.nl/healthcare-providers/ pharmacy-and-drugstore/cost-of-medication-and-service-fees/ (accessed on 7 April 2021).

61. SA Kutsekoda [Qualification Chamber]. The Key Findings of the OSKA Study of the Health Care Sector. 2017. Available online: https:/ / oska.kutsekoda.ee/wp-content/uploads/2016/05/Tervishoid_ENG_16plik.pdf (accessed on 19 May 2021).

62. Luetsch, K. Attitudes and attributes of pharmacists in relation to practice change-A scoping review and discussion. Res. Soc. Adm. Pharm. 2017, 13, 440-455. [CrossRef] [PubMed]

63. Tsuyuki, R.T. A leadership crisis in pharmacy. Can. Pharm. J. 2019, 152, 6-7. [CrossRef] 